\title{
SMOKE for Europe - adaptation, modification and evaluation of a comprehensive emission model for Europe
}

\author{
J. Bieser ${ }^{1,2}$, A. Aulinger ${ }^{1}$, V. Matthias ${ }^{1}$, M. Quante ${ }^{1,2}$, and P. Builtjes ${ }^{3,4}$ \\ ${ }^{1}$ Helmholtz-Zentrum Geesthacht, Institute of Coastal Research, 21502 Geesthacht, Germany \\ ${ }^{2}$ Leuphana University Lüneburg, Institute of Ecology and Environmental Chemistry, 21335 Lüneburg, Germany \\ ${ }^{3}$ Institut für Meteorologie, Freie Universität Berlin, 12165 Berlin, Germany \\ ${ }^{4}$ TNO Built Environment and Geosciences, Air Quality and Climate Team, 3508 TA Utrecht, The Netherlands
}

Received: 9 June 2010 - Published in Geosci. Model Dev. Discuss.: 7 July 2010

Revised: 10 November 2010 - Accepted: 11 November 2010 - Published: 25 January 2011

\begin{abstract}
The US EPA regional emission model SMOKE was adopted and modified to create temporally and spatially distributed emission for Europe and surrounding countries based on official reports and public domain data only. The aim is to develop a flexible model capable of creating consistent high resolution emission data for long-term runs of Chemical Transport Models (CTMs). This modified version of SMOKE, called SMOKE for EUROPE (SMOKE-EU) was successfully used to create hourly gridded emissions for the timespan 1970-2010.

In this paper the SMOKE-EU model and the underlying European datasets are introduced. Emission data created by SMOKE-EU for the year 2000 are evaluated by comparison to data of three different state-of-the-art emission models. SMOKE-EU produced a range of values comparable to the other three datasets. Further, concentrations of criteria pollutants calculated by the CTM CMAQ using the four different emission datasets were compared against EMEP measurements with hourly and daily resolution. Using SMOKE-EU gave the most reliable modelling of $\mathrm{O}_{3}$, $\mathrm{NO}_{2}$ and $\mathrm{SO}_{4}^{2-}$. The amount of simulated concentrations within a factor of 2 (F2) of the observations for these species are: $\mathrm{O}_{3}(\mathrm{~F} 2=0.79, N=329197), \mathrm{NO}_{2}(\mathrm{~F} 2=0.55$, $N=11465)$ and $\mathrm{SO}_{4}^{2-}(\mathrm{F} 2=0.62, N=17536)$. The lowest values were found for $\mathrm{NH}_{4}^{+}(\mathrm{F} 2=0.34, N=7400)$ and $\mathrm{NO}_{3}^{-}$ $(\mathrm{F} 2=0.25, N=6184)$. $\mathrm{NH}_{4}^{+}$concentrations were generally overestimated, leading to a fractional bias (FB) averaged over 22 measurement stations of $(F B=0.83 \pm 0.41)$ while
\end{abstract}

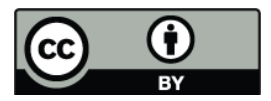

Correspondence to: J. Bieser (johannes.bieser@hzg.de) better agreements with observations were found for $\mathrm{SO}_{4}^{2-}$ ( $\mathrm{FB}=0.06 \pm 0.38,51$ stations $)$ and $\mathrm{NO}_{3}^{-}(\mathrm{FB}=0.13 \pm 0.75$, 18 stations).

CMAQ simulations using the three other emission datasets were similar to those modelled using SMOKE-EU emissions. Highest differences where found for $\mathrm{NH}_{4}^{+}$while $\mathrm{O}_{3}$ concentrations were almost identical.

\section{Introduction}

Chemistry transport models (CTMs) are used for a variety of purposes (air quality modelling, source attribution, assessment of abatement strategies, etc.) with modelling domains ranging from global coverage down to local scales. In addition to the meteorological data, lack of knowledge on emissions introduces a major uncertainty in the CTM modelling results (Russell, 2000; Seaman, 2000; Hanna and Davis, 2001; Anderson and Langner, 2005; Sofiev et al., 2009).

In general there are two ways of modelling emissions. The "Bottom-Up" approach models emissions by combining sources with activities and emission factors. By definition, the source is the spatial location of the emitter, the activity is the temporal emission pattern and the emission factor determines the amount of pollutants emitted (Benkovitz, 2004). This approach is practicable for uniform sources. Bottom-up is mostly used for biogenic and mobile sources since they can be combined to a limited number of source types (e.g., coniferous trees, broadleaf trees for biogenic emissions; diesel vehicles, gasoline vehicles for mobile sources). The opposite methodology, the "Top-Down"

Published by Copernicus Publications on behalf of the European Geosciences Union. 
approach is used for groups of disparate sources which can not be easily combined but for which regional annual total emissions can be estimated from sales, usage or other statistics (e.g., power plants). These estimated annual total emissions are also called emission inventories. They are usually separated into several source sectors combining chemical processes (e.g., combustion, solvents) and/or economic units (e.g., industry, private households). For the use in CTMs these aggregated emissions are spatially and temporally disaggregated using spatial surrogates and temporal profiles. A spatial surrogate is a proxy for the fraction of the total emissions emitted in each grid cell. Because there are only a limited amount of European emission inventories and surrogates, all emission models use similar types of input data. The datasets used for SMOKEEU are introduced in greater detail in Sect. 2.

Besides proprietary emissions models, which are not publicly available, there are several public models. Each of these models has its own restrictions, e.g., compatibility to a certain CTM, temporal coverage, spatial resolution for regional modelling or the focus on a single nation or region. The EMEP emission data provided by MSC-W have a large temporal coverage for all of Europe with spatial resolution of $50 \times 50 \mathrm{~km}^{2}$. Temporally disaggregated emissions are not published (Webdab, 2010). The Dutch CTM LOTOSEUROS developed by TNO and RIVM as well as the French CTM CHIMERE have their own emission models producing suitable emission data (Schaap et al., 2005; Vautard et al., 2007). Yu et al. adapted the SMOKE model to prepare emission data for the UK. The Dutch TNO and the German IER emission models are two widely used emission models capable of producing high resolution emissions (Friedrich and Reis, 2004; Visschedijk et al., 2007) but are not public. However, the emission datasets calculated by TNO can be obtained free of cost. The EDGAR emission database contains emissions of air pollutants on a $1 \times 1$ degree grid for the years 1990, 1995 and 2000 (Olivier, 2001). The mentioned models are only representative examples of the European emission models. Given the variety of emission models available for Europe the question arises, "What benefit can be gained from an additional model?" The rational for this emission model is to provide a flexible tool capable of creating consistent high resolution emission datasets for long-term CTM runs over Europe based only on open source data. Flexibility means that the model can be easily altered as regards the input data and output format and that new species, or different photochemical splits, can be included with a minimum amount of work. Consistency requires that emissions for each year are calculated using similar input data and the same algorithms. This consistency in approach is in contrast to many emission models, which use the best available data for each new report year, with report years usually being every five or ten years. Such an approach leads to a steady improvement of the emission datasets but comes at the cost of compatibility with older datasets, since these older report years are not compatible with the new methodologies. The model introduced in this paper is specifically designed for long-term CTM runs and, thus, needs to overcome these problems.

For the evaluation of SMOKE-EU, datasets from three widely used emission models are used. These are the TNOGEMS datasets created with the TNO model, a purchased dataset from IER further called IER-GKSS and the official EMEP emissions. These emission datasets are introduced in further detail in Sect. 3.1. The emissions are compared with respect to the total emissions, the spatial distribution and the temporal distribution. Furthermore, all four emissions datasets are being used as input for the CMAQ (Community Multiscale Air Quality) CTM for the year 2000. The calculated air concentrations of the species $\mathrm{O}_{3}, \mathrm{NO}_{2}, \mathrm{NO}_{3}^{-}$, $\mathrm{SO}_{2}, \mathrm{SO}_{4}^{2-}$ and $\mathrm{NH}_{4}^{+}$are compared with measurements from rural measurement sites. These comparisons are thoroughly described in Sect. 4.

\section{Methodology}

The emission model SMOKE is the official emission model of the Unites States Environmental Protection Agency (US EPA) and is one of the most used emission models world wide (Houyoux et al., 2000; MCNC Environmental Modelling Centre, 2008; UNC Carolina Environmental Program, 2005). SMOKE was originally created by the MCNC Environmental Modelling Centre (EMC) and developed further by the US EPA. It is the official emission model of the Models-3 Community Modelling and Analysis System (CMAS) and creates emission data suitable for CMAQ (Byun and Ching, 1999; Byun and Schere, 2006). Anthropogenic emissions are calculated using the "TopDown" methodology while biogenic emissions are calculated by the Bottom-Up model BEIS3 (Guenther et al., 2000; Pierce et al., 1998; Schwede, 2005). Although SMOKE is highly specialized for usage with officially reported data in the US, there have been several successful attempts to use it for other regions. In Europe, for example, SMOKE has been adapted to use the national emission inventories of Spain and the UK (Borge et al., 2008; Yu et al., 2008).

The SMOKE emissions model uses a modular setup (Fig. 1). Area, point, mobile and biogenic sources are calculated by different modules and merged into a single output file. Short descriptions of the major modules for area and point source processing and their function, as well as the modules of the biogenic bottom-up model BEIS3, can be found in Appendix A. In order to run SMOKE, four kinds of data are needed for the different species: the bulk emission inventory, spatial surrogates, speciation profiles and temporal profiles. For plume rise calculations and biogenic emissions certain meteorological input data are needed additionally (e.g., temperature, radiation, wind, humidity). 


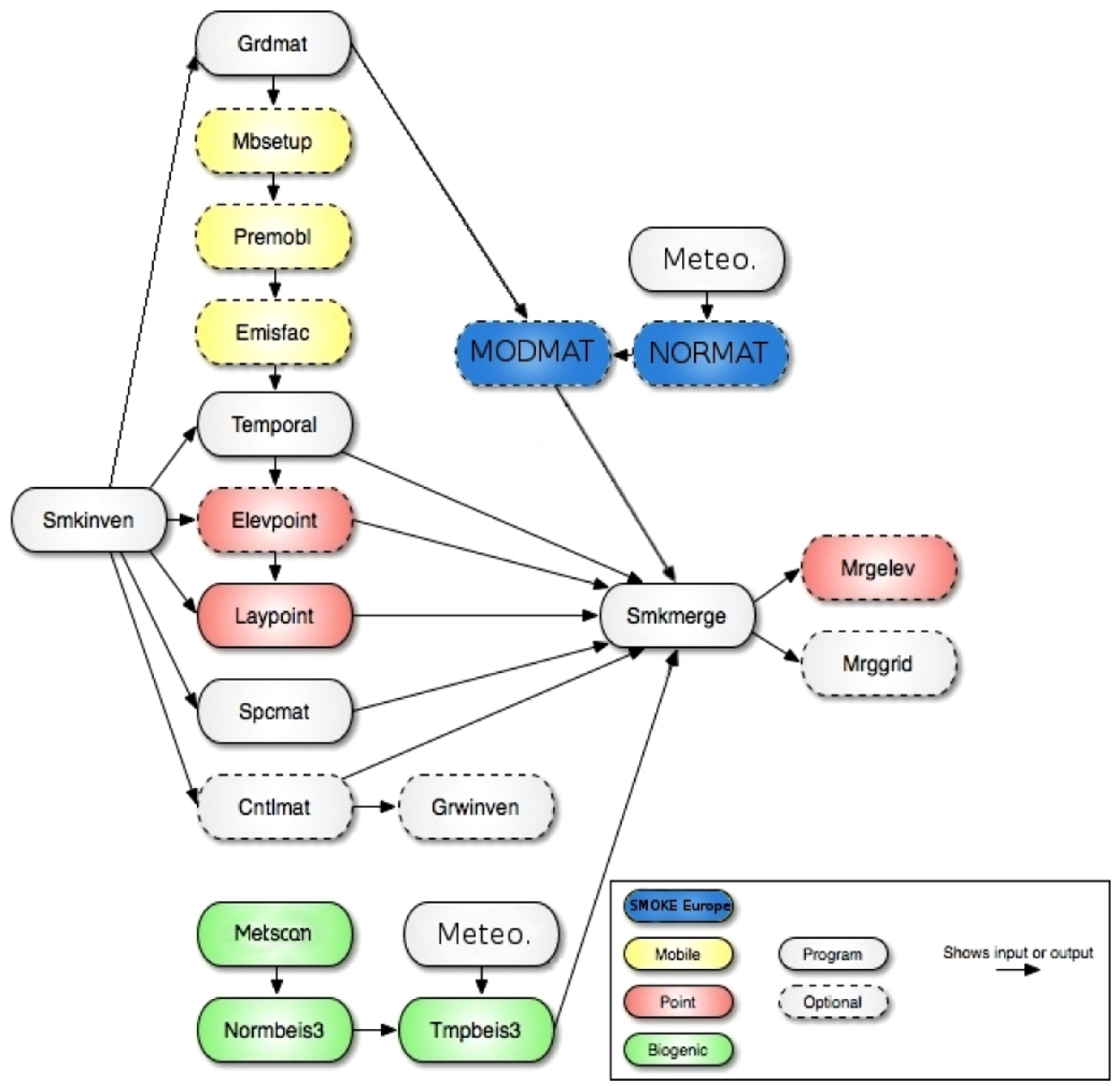

Fig. 1. SMOKE and BEIS3 (green) core programmes including modifications for SMOKE EUROPE (blue). Short descriptions of the most important modules can be found in Appendix A (Baek et al., 2009).

The Smkinven module reads the data in the inventory file which contains the aggregated emissions distinguished by a 6 digit regional code FIPS (US Federal Implementation Planning Standards) and a 10 digit source code SCC (Source Classification Code). In the US, the emission inventories are usually published at county level, leading to a high spatial resolution. Also the 10 digit SCC code allows for detailed partitioning of source types. The subsequent SMOKE modules search for different profiles matching the FIPS and SCC codes of each emission source, using the best fit if no exact match is possible (Baek et al., 2009).

\subsection{SMOKE for EUROPE (SMOKE-EU)}

The SMOKE model has been under development for over a decade. Therefore, it is highly specialized on the usage of official data of the US. Since this model setup is not directly compatible to European data reporting schemes, several adjustments need to be made for the use of SMOKE for Europe.
In order to achieve a high spatial resolution, SMOKE uses emission aggregates on county basis and distributes them using static surrogates for each region. This is done by the Grdmat module which creates a single, static gridding matrix (GRDMAT) for each year. When used with European emissions aggregated on the national level, these static surrogates lead to a static spatial distribution for each country over the whole year. This is a valid assumption for sources that are spatially static, for example, mobile emissions which are connected to the road network throughout the year. For emissions that are influenced by local events, such as combustion for heating, static surrogates in combination with large or heterogeneous regions can lead to an unrealistic emission distribution. This is due to the fact that the spatial distribution of heating demand is not static throughout the year but changing depending on the temperature. Furthermore, the temporal disaggregation in SMOKE is done via monthly, weekly and hourly profiles. This can lead to large emission changes between the last day of a month and the first day of the next month. 
In order to overcome these restrictions of SMOKE, in SMOKE-EU a new module has been introduced whose basic function is to create a distinct gridding matrix (GRDMAT) for each day of the year. This matrix, because it modifies the gridding matrix for each day, is called the modification matrix (MODMAT) and the module calculating it Modmat. By definition, unless parts of the surrogate are outside the modelling domain, the sum of each surrogate is always 1 (Eq. 1). This is also true for the average of all modification matrices (Eq. 2) but not for each single daily modification matrix (Eq. 3). The changing sum of each modification matrix for each day represents an annual temporal profile for each grid cell, thus, replacing the monthly temporal profiles used by the original SMOKE model.

$$
\begin{aligned}
& \sum_{i=1}^{N} \operatorname{GRDMAT}(i)=1 \\
& \mathrm{~N}=\text { number of grid cells } \\
& \frac{\sum_{i=1}^{N}\left[\sum_{j=1}^{T} \operatorname{MODMAT}(i, j)\right]}{T}=1 \\
& \sum_{i=1}^{N} \operatorname{TO} \operatorname{MoDM} \operatorname{nom} \text { of time steps }\left(365 \text { days }^{N} \operatorname{year}^{-1}\right)
\end{aligned}
$$

Equation (4) shows the calculation of gridded emissions by SMOKE. For each species, hourly emissions in $\mathrm{g} \mathrm{s}^{-1}$ or mole $\mathrm{s}^{-1}$ are calculated by multiplying the gridding matrix (GRDAMT), the speciation matrix (SPCMAT), the emission profile matrix (EP) and the temporal factors (TMPFAC) with the annual total emissions (TOT). Since it is not time dependent, the gridding matrix is calculated only once for each year (Eq. 4).

$$
\begin{aligned}
& E(t, x, y, z)=\operatorname{GRDMAT}(x, y) \cdot \operatorname{SPCMAT}(x, y) \\
& \cdot \mathbf{E P}(z) \cdot \mathbf{T M P F A C}(t) \cdot \mathrm{TOT}
\end{aligned}
$$

The Modmat module calculates separate gridding matrices for each day as indicated by Eq. (5). For better readability, the horizontal dimensions $x$ and $y$ have been substituted by the grid cell number $n$. The change matrix $\operatorname{CHGMAT}(n, t)$ is calculated from external files. Here, for all emissions from heating, change factors have been calculated using the $2 \mathrm{~m}$ temperature as a proxy for heating demand (Aulinger, 2010). For each day, the gridding matrix (GRDMAT) is multiplied with the change matrix (CHGMAT) and normalized. The normalization matrix (NORMAT) is calculated once by multiplying the static gridding matrix with the change matrix (Eq. 6).
$\operatorname{MODMAT}(n, t)=$

$$
\frac{\operatorname{GRDMAT}(n) \cdot \operatorname{CHGMAT}(n, t) \cdot T \cdot \sum_{i=1}^{N}[\operatorname{GRDMAT}(i)]}{\operatorname{NORMAT}(n)}
$$

$\operatorname{NORMAT}(n)=$

$$
\sum_{i=1}^{N}\left[\operatorname{GRDMAT}(i) \cdot \sum_{j=1}^{T}[\operatorname{CHGMAT}(i, j)]\right]
$$

While the annual total emissions remain unchanged, the spatial as well as the temporal distribution vary. This leads to a mixture of spatial and temporal disaggregation. Thus, the originally applied monthly profiles are redundant, since they are already represented by the 365 daily modification matrices.

Although several changes to the original SMOKE source code have been made, SMOKE-EU is not a completely new emission model. It is rather a specific setup of the SMOKE model which can be used to prepare high resolution emission data for Europe. A large part of SMOKE-EU is the numerous input files needed in order to run SMOKE for Europe. These datasets and their usage is described in the following sections.

\subsection{Emission inventories}

European emission inventories and datasets are quite heterogeneous. Most countries use different methodologies to assess their national emissions. This results in different national emission inventories, possibly using different emission factors, for similar sources and allocation of these to different source categories. Amongst those countries which do publish their emission inventories, most countries use a national map projection making transformation of the data necessary. For SMOKE-EU it was decided to aim for overall consistency by using Pan-European datasets when available.

\subsubsection{The European Monitoring and Evaluating Programme (EMEP)}

Initiated by the Convention on Long-range Transboundary Air Pollution (LRTAP), signed in 1979, the European Monitoring and Evaluation Programme (EMEP) was implemented. National annual emission estimates are reported by the parties under the LRTAP convention, using the standardized methods defined by the CORINAIR (CORe Inventory of AIR emissions) guidebooks (Vestreng, 2007; Webdab, 2010). The officially submitted data is published together with a corrected version that was reviewed by national experts.

EMEP publishes annual national totals for all European countries, including Russia, and also Turkey and North Africa. The species covered by the EMEP inventory are CO, 
Table 1. SNAP: Selected Nomenclature for sources of Air Pollution.

\begin{tabular}{ll}
\hline Sector & Description \\
\hline SNAP 1 & Combustion in energy and transformation industries \\
SNAP 2 & Non-industrial combustion plants \\
SNAP 3 & Combustion in manufacturing industry \\
SNAP 4 & Production Processes \\
SNAP 5 & Extraction and distribution of fossil fuels and \\
& geothermal energy \\
SNAP 6 & Solvent use and other product use \\
SNAP 7 & Road transport \\
SNAP 8 & Other mobile sources and machinery \\
SNAP 9 & Waste treatment and disposal \\
SNAP 10 & Agriculture \\
SNAP 11 & Other sources and sinks \\
\hline
\end{tabular}

$\mathrm{NO}_{\mathrm{x}}, \mathrm{SO}_{2}, \mathrm{NH}_{3}$, Non-Methane Volatile Organic Compounds (NMVOC), primary particulate matter (PM) as $\mathrm{PM}_{10}$ and $\mathrm{PM}_{2.5}$, several Heavy Metals (HMs) and some Persistent Organic Pollutants (POPs). The emissions are distributed over 11 SNAP source sectors (Selected Nomenclature for sources of Air Pollution) (Table 1). SNAP is a standard defined by the CORINAIR guidebooks which ensures that emissions reported by different nations are compatible (European Environmental Agency, 2007). EMEP covers the years 1970-2009 with additional projections for 2010, 2015 and 2020. In addition to the national reports, emissions from international shipping are included in the inventory.

\subsubsection{The European Pollutants Emission Register (EPER)}

EPER is the European Pollutant Emission Register, the first Europe-wide register of industrial emissions into air and water, which was established by the European Commission in July 2000 (European Commission, 2000). EPER has been released for two base years. For the EU15 (Austria, Belgium, Denmark, Finland, France, Germany, Greece, Ireland, Italy, Luxembourg, the Netherlands, Portugal, Spain, Sweden and the UK) in 2001 and for the EU27 (EU15 + Bulgaria, Cyprus, Czech Republic, Estonia, Hungary, Latvia, Lithuania, Malta, Poland, Romania, Slovakia and Slovenia) in 2004. There are considerable differences between the emission data released in 2001 and 2004, mainly due to the fact that the 2004 data is more complete. We have used only the 2004 inventory for point source modelling (European Pollution Emission Register, 2010). It covers approximately 12000 industrial point sources with information about annual total emissions, source code and geographical location. The NACE (Nomenclature statistique des activités économiques dans la Communauté européenne) code is a more sophisticated source identifier than the SNAP code. It consists of several hundred different source types, especially distinguishing between different industries. A large percentage of NACE codes are covered by SNAP 3 and SNAP 4.

\subsubsection{Merging EMEP and EPER into a combined emission inventory}

Since the EPER inventory includes the exact geographical location of each source, no surrogates are needed to estimate the spatial distribution of the emissions. Furthermore, the industrial processes of each source are known. This allows for a more precise estimation of the effective emission heights. Because of this, EPER sources are considered more precise than EMEP sources. Since EPER only contains major point sources, the missing emissions are taken from the EMEP inventory which is an estimate of the national total emissions. This is done by the subtraction of EPER from EMEP. In very few cases the EPER emissions, for a certain species and sector, exceed the EMEP emissions. In those cases EPER emissions are used, leading to slightly higher emissions than reported in the EMEP inventory. The preparation of the SMOKE-ready inventory files is done by a newly written java-based preprocessor called InvenCombine. The calculations are done in three steps:

1. Conversion of EPER from NACE to SNAP sectors.

2. Adjustment of the EPER base year 2004 emissions to the modelling year.

3. Merging of the two inventories.

While most sectors can be converted directly, there are still some incompatibilities between the two systems. NACE has a wide range (more than 100) of industrial sources, distinguished by industrial sector, while SNAP differentiates between two general processes - industrial combustion (SNAP 3) and manufacturing and industrial processes (SNAP 4)

In order to correctly convert the EPER data, for each region and for each species, all NACE classes fitting into SNAP 3 and SNAP 4 are first combined into a single sector and then redistributed depending on the ratio of SNAP 3 to SNAP 4. In a second step, the 2004 EPER data is attributed to each SNAP sector and each species according to the relative change of EMEP emissions between 2004 and the inventory year. Finally the SNAP converted and adjusted EPER emissions are subtracted from the EMEP emissions.

\subsection{Spatial surrogates}

Spatial surrogates are the proxies used to allocate the national total emissions to the emissions model grid. The sum of each surrogate is 1 , by definition, unless parts of the country for which the emissions have been aggregated are outside the model domain (e.g., Russia). If there are no specific surrogates for a certain region the population 
Table 2. Spatial surrogates used for different SNAP sectors and biogenic emissions. A list of abbreviations can be found in Appendix C.

\begin{tabular}{ll}
\hline Sector & Datasets used for spatial disaggregation \\
\hline SNAP 1 & EPER, CLC (commercial and industrial units), GLC (urban area), GPWv3 \\
SNAP 2 & GPWv3, 2 m temperature \\
SNAP 3 & EPER, CLC (commercial and industrial units), GLC (urban area), EUROSTAT (employees in industry), GPWv3 \\
SNAP 4 & EPER, CLC (commercial and industrial units), GLC (urban area), EUROSTAT (employees in industry), GPWv3 \\
SNAP 5 & EPER, CLC (ports), GPWv3 \\
SNAP 6 & GPWv3 \\
SNAP 7 & TREMOVE, OSM and DCW (motorways, roads), CLC (urban area), GLC (urban area) \\
SNAP 8 & TREMOVE, CLC and GLC (airports, agricultural areas), OSM and DCW (railways, waterways, roads) \\
SNAP 9 & CLC (dump sites), GPWv3 \\
SNAP 10 & CLC (agricultural areas, pastures), GLC (agricultural areas), EUROSTAT (employees in agriculture, animal stocks) \\
Biogenic & GsfM (Tree distribution), CLC (land use), GLC (land use) \\
\hline
\end{tabular}

density is used as the basis for anthropogenic emissions. Maes et al. (2009) showed that disaggregating the combined EPER and EMEP emissions with European datasets leads to spatially distributed emissions comparable to high resolution national emission inventories. A list of datasets used for each SNAP sector is shown in Table 2. All surrogate input datasets are interpolated to the SMOKE-EU modelling domain and converted to the SMOKE format by several preprocessors. In the following, the surrogate datasets are briefly described:

Gridded Population of the World version 3 (GPWv3) depicts the distribution of human population across the globe. It contains globally consistent and spatially explicit human population information and data. It is released for every fifth year starting in 1990 on a $2.5^{\prime} \times 2.5^{\prime}$ resolution. Furthermore, future projections until 2015 are available (Balk, 2004; Sedac, 2010). The GPWv3 population density dataset is used as the default surrogate.

Corine Air Land Cover (CLC) dataset was created by the European Environmental Agency (EEA) and is freely available (Corine Land Cover, 2010). So far the dataset has been released for 1990, 2000 and 2006. CLC distinguishes 45 different land use classes with a spatial resolution of $100 \times 100 \mathrm{~m}^{2}$. It covers all member states of the European Union.

Global Land Cover (GLC2000) dataset provided by the Land Cover Institute of the United States Geological Survey (USGS) is a global land use database. It was released once, for the year 2000 , with $1 \times 1 \mathrm{~km}^{2}$ resolution. It distinguishes 24 different land use classes. The GLC2000 data was used as a surrogate for all regions without CLC coverage (USGS, 2009).

Openstreetmaps (OSM) is a public domain vector database combining GPS (Global Positioning System) data from thousands of volunteers around the world. It contains a free global street and land use map. Since the start of the project in 2004, almost complete coverage of streets and railroads in the EU has been achieved. The 2009/12 version of OSM has been used to create surrogates of motorways, major rural roads and railways (Openstreetmap, 2010).

Digital Chart of the World (DCW) is a public domain vector database developed by the Environmental Systems Research Institute, Inc. (ESRI) for the US Defense Mapping Agency (DMA). It contains data on roads, railways and waterways. The DCW is freely available for the year 1992 (Digital Chart of the World, 1992). This dataset has been used to disaggregate mobile emissions before 1993. Between 1993 and 2000, an interpolated dataset consisting of OSM and DCW is used.

GSfM Land Use Database is a compilation of different land use datasets. Besides other land use data it contains the Forest database (JRC/TNO), which distinguishes 136 different tree types and was created for UBA (Federal Environment Agency), and the CLC2000 landuse dataset (Smiatek, 1998). Since the CLC dataset distinguishes only between 5 forest types, the UBA forest database was used to determine the tree coverage for the biogenic emissions model BEIS3. Land use dependent emissions like NO are calculated using the CLC database.

TREMOVE is a policy assessment model, designed to study the effects of different transport and environment policies on the emissions of the transport sector (EC, 2007). The model provides estimates for policies such as road pricing, public transport pricing, emission standards, subsidies for cleaner cars etc., the transport demand, modal shifts, vehicle stock renewal and scrappage decisions as well as the emissions of air 
Table 3. NUTS level definition.

$\begin{array}{lr}\text { NUTS } 1 & 3 \text { million-7 million inhabitants } \\ \text { NUTS } 2 & 800000-3 \text { million inhabitants } \\ \text { NUTS } 3 & 150000-800000 \text { inhabitants }\end{array}$

pollutants and the welfare level. It models both passenger and freight transport and covers the period 1995-2030 (TREMOVE, 2010). The v2.7b Basecase dataset of the TREMOVE bottom-up emission model has been used to split the EMEP emissions estimated for sector SNAP 7 (Road transport) into motorway, rural and urban subsectors as well as to distinguish between different vehicle and fuel types. The EMEP sector SNAP 8 (Other mobile transport) is split into the subsectors transport by rail, inland shipping and airplanes.

EUROSTAT is the statistical service of the European Union. It releases statistics concerning the economy, environment, society, industry, agriculture and regional development (EUROSTAT, 2010). Some EUROSTAT statistics date back as far as 1953. All statistical values are reported using the Nomenclature of Units for Territorial Statistics (NUTS) geocode standard which is the official European system for referencing subdivisions of countries (European Commission, 2003). NUTS regions are defined by the amount of inhabitants (Table 3). The EUROSTAT data is usually available as monthly national or annual regional values, with regional values going down to NUTS3 level. The EUROSTAT regional statistics on NUTS2 level are used to further disaggregate industrial and agricultural emissions depending on the number of employees in certain industries, number of employees in agriculture and animal stocks for $\mathrm{NH}_{3}$ emissions from animals.

\subsection{Vertical distribution}

For the use in CTMs it is still common to apply static vertical distribution factors to the emissions of each sector or even to put all emissions into the lowest layer. With effective emission heights of industrial sources in the range of $100 \mathrm{~m}$ to $600 \mathrm{~m}$ Plume rise calculations can have a strong impact on the calculated air concentrations and depositions. Emissions in higher layers are likely to be transported further away from the source, wet depositions are less if a higher amount of pollutants is above the cloud layer and particles need longer until they reach the ground by dry deposition giving them more time for interaction with other species. For example, comparisons of different CTM runs showed a change in the $\mathrm{SO}_{4}^{2-}$ to $\mathrm{SO}_{2}$ ratio depending on the emission height.
All non-VOC emission sources from the SNAP sectors $1,3,4,5$ and 9 are treated as elevated sources. VOC emissions from dump sites (SNAP 9) are interpreted as surface evaporations and, thus, are not elevated. Data for stack height, stack diameter, exit velocity and exit temperature are applied to all EPER sources depending on NACE sector following Pregger and Friedrich (2009). All emissions not covered by EPER are first horizontally distributed as described in Sect. 2.3 and then supplemented with average stack data depending on SNAP sector. For countries covered by EPER it is assumed that the remaining sources are only minor sources, thus, having lower average stack heights than their corresponding EPER sources. For those countries not covered by EPER, a sectoral emissionweighted average is built using stack data for major sources. The vertical distribution of emissions by point sources is calculated using the SMOKE module Laypoint. It calculates the effective emission heights using the Briggs plume rise equations. (Briggs, 1972; Houyoux, 1998). This leads to different effective emission heights depending on the meteorological fields used as input for the PiG calculations.

\subsection{Temporal distribution}

SMOKE-EU uses the LOTOS-EUROS monthly, weekly and diurnal profiles which features distinct profiles for each SNAP sector (Builtjes, 2003). For SNAP sector 2 (Nonindustrial combustion plants) the $2 \mathrm{~m}$ temperature is used to create the annual temporal profiles using the Modmat module (Aulinger, 2010). This leads to a more realistic, year specific temporal disaggregation. While currently all other SNAP sectors use the static LOTOS-EUROS profiles for temporal disaggregation, there are other possible applications for Modmat. For example, it seems promising to use the soil moisture as an additional proxy for $\mathrm{NH}_{3}$ emissions from agricultural areas.

The biogenic emissions which are calculated by the bottom-up model BEIS3 are temporally disaggregated using meteorological fields. VOC emissions of trees are depending on the near surface temperature $(2 \mathrm{~m}-10 \mathrm{~m})$ and the incoming radiation. Biogenic NO emissions are depending on soil moisture and soil temperature.

\subsection{Chemical speciation}

Some substances in the emission inventories are composites of many different distinct species. For all CTMs, volatile organic compounds (VOC) need to be separated into several organic species, depending on the photochemical mechanism in use. Nitrogen oxides are usually reported as $\mathrm{NO}_{\mathrm{x}}$ and need to be split into $\mathrm{NO}$ and $\mathrm{NO}_{2}$. SMOKE-EU currently splits all $\mathrm{NO}_{\mathrm{x}}$ emissions into $90 \% \mathrm{NO}$ and $10 \% \mathrm{NO}_{2}$ (EPA, 2010). Besides this there can be other substances which need to be speciated, such as primary particulate matter for CMAQ. SMOKE is able to split any species from the bulk 
emission inventory into arbitrary subspecies. This makes it easy to adjust the emission model to match different chemical mechanisms and other user demands.

Primary Particulate Matter (PM) in the bulk emission inventory is separated into two size classes. These are particles smaller than $10 \mu \mathrm{m}\left(\mathrm{PM}_{10}\right)$ and particles smaller than $2.5 \mu \mathrm{m}\left(\mathrm{PM}_{2.5}\right)$. For CMAQ $\mathrm{PM}_{2.5}$ needs to be further speciated into primary elemental carbon (PEC), primary organic aerosols (POA), primary nitrate aerosols $\left(\mathrm{PNO}_{3}\right)$, primary sulfate aerosols $\left(\mathrm{PSO}_{4}\right)$ and other particles (PMFINE). Each of the 10 SNAP sectors has its own PM split, while some sectors also have splits on sub-sector level. Vehicles, for example, have different PM splits depending on vehicle type (Heavy Duty Vehicles, Light Duty Vehicles, Buses) and fuel type (Diesel, Gasoline). The PM splits were adopted from the SMOKE emission model (EPA, 2010). Additionally, split factors for emissions from international shipping have been implemented (Agrawal, 2008).

Volatile Organic Compounds (VOCs) need to be speciated according to the photochemical mechanisms used by the CTM. At this point SMOKE Europe supports VOC splits for the mechanisms Carbon Bond 4 (CB-IV) and Carbon Bond 5 (CB05) (Gery et al., 1989). New photochemical mechanisms can be easily implemented by supplying the split factors for each SNAP sector. The split factors have been calculated using the chemical VOC analysis of Passant (2002).

\section{Evaluation of the emission data}

First of all, the impact of the Modmat module on the spatial and temporal disaggregation of the emissions is assessed. This is done by the comparison of two different datasets created with SMOKE-EU. The first emission dataset, the default case, uses only static temporal profiles and surrogates. The second dataset is created using the Modmat module for the calculation of emissions from residential heating (SNAP 2). In this case Modmat uses the $2 \mathrm{~m}$ temperature from meteorological input fields as a proxy for heating demand (Aulinger, 2010).

In a second step, the SMOKE-EU emissions for the year 2000 are statistically compared to three state-of-the-art emission datasets. The comparison is done separately for the 6 inventory species: $\mathrm{NO}_{\mathrm{x}}, \mathrm{SO}_{2}, \mathrm{CO}, \mathrm{PM}_{10}, \mathrm{NH}_{3}$, VOC. First, the total emissions for the EU27 countries are compared, then the horizontal, vertical and temporal distributions of the different emission datasets are compared. Only selected figures are shown for each statistical comparison.

\subsection{Emission datasets used for comparison}

In order to evaluate the emissions created by SMOKE-EU three emission datasets calculated by widely used models have been used for comparison. These datasets will be

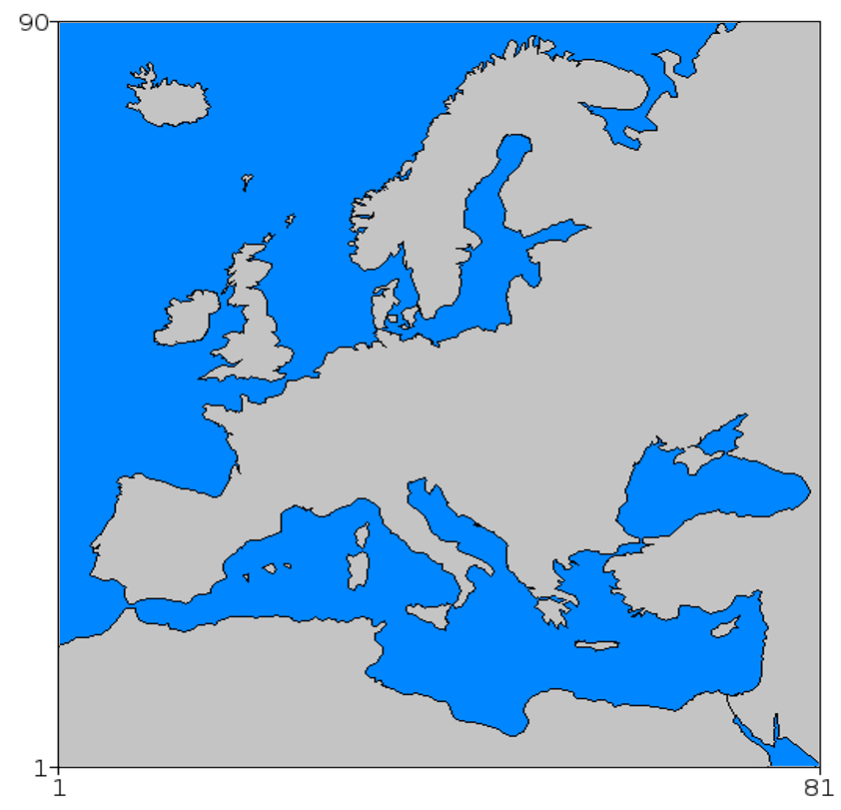

Fig. 2. Modelling domain used for CTM calculations with $54 \times 54 \mathrm{~km}^{2}$ grid resolution and 30 vertical layers.

referred to as EMEP, IER-GKSS and TNO-GEMS. All emission datasets are compared for the GKSS $54 \times 54 \mathrm{~km}^{2}$ modelling domain (Fig. 2).

$E M E P$ : the EMEP emission dataset created by the Meteorological Synthesizing Centre - West (MSC-W) is based on the EMEP emission inventory. Species covered are $\mathrm{CO}, \mathrm{NO}_{\mathrm{x}}, \mathrm{SO}_{2}, \mathrm{NH}_{3}, \mathrm{PM}_{10}, \mathrm{PM}_{2.5}$ and NMVOC. The spatial distribution of the emissions for each SNAP sector is provided by the national authorities every five years. The methodology used for the preparation of these gridded data can differ for each country. For countries without information on the spatial distribution of emissions the population density is used as a proxy. In the reporting year 2010, of 48 Parties which are considered for the extended EMEP area, only 16 Parties reported sectoral gridded data for the year 2000 and 23 Parties reported sectoral gridded data for 2005 (Mareckova et al., 2010). EMEP still has to perform the spatial distribution of emissions for more than half of the European countries by applying its own methods (Mareckova, 2008). For the temporal disaggregation of the annual emission estimates IER temporal profiles for air quality calculations are used by the EMEP unified model (Benedictow et al., 2009; Simpson et al., 2003). Still only gridded annual totals on a $50 \times 50 \mathrm{~km}^{2}$ domain together with SNAP specific vertical profiles are published by EMEP (Webdab, 2010). The LOTOS-EUROS temporal profiles have been used for temporal disaggregation in this comparison.

IER-GKSS: an emission dataset for the GKSS $54 \times 54 \mathrm{~km}^{2}$ modelling domain over Europe was purchased from the University of Stuttgart Institute for Rational Use of 
Energy (IER) and is here referred to as IER-GKSS. The IER emissions model is based on the EMEP/CORINAIR emission guidebooks. It features distinct temporal profiles for each country and SNAP sector as well as VOC and PM splits. The dataset purchased by GKSS has no vertical distribution (Friedrich and Reis, 2004).

TNO-GEMS: the Netherlands Organization for Applied Scientific Research (TNO) GEMS emissions are a $0.125 \times 0.0625$ degrees dataset created by the TNO emission model for the EU FP7 project GEMS (Global and regional Earth-system Monitoring using Satellite and in situ data). For the preparation of this emission dataset, the official European national annual total emissions reported for the 11 SNAP sectors have been split into sub-sectors and spatially distributed according to proxy data. For point sources, the exact geographical location of major combustion plants, oil refineries, oil and gas production facilities (including off-shore), coke ovens, iron and steel plants, non-ferrous metals smelters, cement factories, chemical plants, waste incinerators and major airports in Europe are used. Area sources are distributed using European datasets, namely location and (partly) traffic intensities of highways and major secondary roads, urban, rural and total population density, distribution patterns of various agricultural activities, a detailed land use and land cover dataset, the locations and densities of forested areas and the location and densities of sea shipping routes on European seas (Visschedijk and Denier van der Gon, 2005). For temporal disaggregation of the annual emissions the TNO model uses hourly, daily and monthly emission factors for each species and country. The emissions are vertically distributed using the SNAP dependent EMEP profiles. The TNO-GEMS dataset is scaled to match the EMEP emissions for 2003 (Visschedijk et al., 2007).

\subsection{Evaluation of the impact of the Modmat module}

SMOKE-EU has been set up to process anthropogenic emissions from the sector SNAP 2 of the EMEP emission dataset. The default scenario uses the population density as a static surrogate for SNAP 2 sources and LOTOSEUROS temporal profiles. SNAP 2 emissions are mostly due to residential heating and, thus, correlated to the near surface temperature. The modified scenario uses the $2 \mathrm{~m}$ temperature from meteorological fields as input data for the Modmat module, which in this case calculates daily gridding matrices using the average heating demands related to specific emissions (Aulinger, 2010). This changes the spatial as well as the annual temporal distribution.

Comparing the two emission datasets revealed two major effects of the Modmat module. As expected these correlate with the size of the aggregated region. The largest differences between the default and the modified scenario could be observed for the spatial disaggregation of large regions or regions with strong temperature gradients.
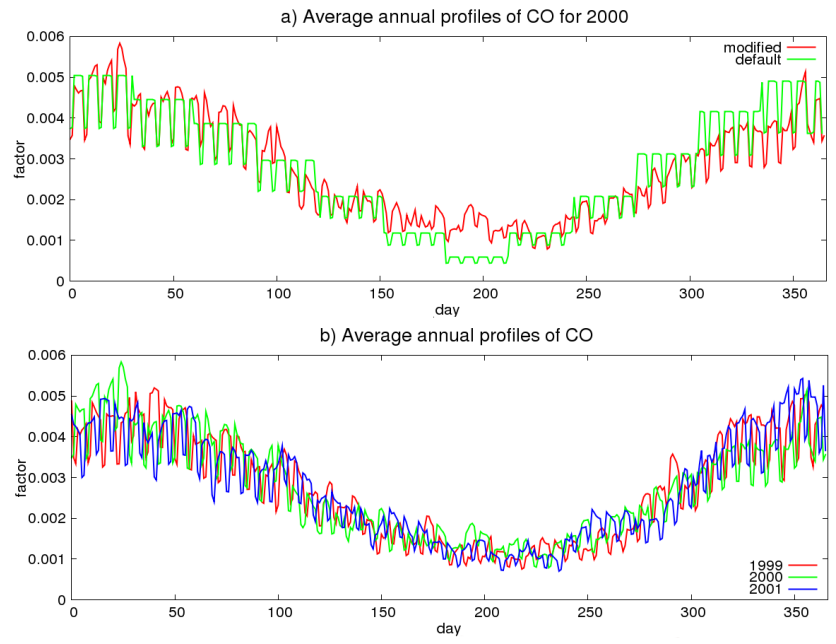

Fig. 3. All values are averaged over the whole $54 \times 54 \mathrm{~km}^{2}$ domain (Fig. 2) for the year 2000. (a) Comparison of temperature dependent temporal profiles SMOKE default with the modified version. (b) Inter annual comparison of temperature dependent $\mathrm{CO}$ temporal profiles.

For Switzerland, which is one of the smallest European countries, differences of up to $20 \%$ in annual total emissions have been found in certain grid cells. This can be explained by differences in the annual heating demand north and south of the Alpes. The annual total emissions for the whole country did not change. Also the annual temporal disaggregation no longer follows monthly average profiles. This leads to a smoothing of the annual profiles and avoids the sometimes strong emission changes at the end of each month (Fig. 3a). Additionally each year now has a unique temporal profile, making the Modmat module particularly interesting for long-term runs. It can be seen that in the year 2000 more heating occurred in January than in December, while the years 1999 and 2001 show the opposite (Fig. 3b). The inter annual variability of the temporal profiles is as high as the deviation between the default and modified SMOKEEU version.

In order to assess the impact of Modmat in the default SMOKE-EU version on air concentrations, the emissions from both the default and the modified scenario were used as input for the CMAQ CTM. For 250 rural grid cells daily average calculated air concentrations for $\mathrm{SO}_{2}, \mathrm{NO}$ and $\mathrm{CO}$, the three main emitted substances in SNAP 2, have been compared to one another. The statistical indicators used for comparison are the Mean Normalized Error (MNE) and the Mean Normalized Bias (MNB) (Appendix B). The average MNE is $20 \%(6 \%$ to $56 \%)$ with a MNB of $9 \%(-18 \%$ to $50 \%)$. When comparing the concentrations calculated using the complete emission datasets with all EMEP and EPER emission sources, values are: $\mathrm{MNE}=3.5 \%(0.8 \%$ to $49 \%)$ and $\mathrm{MNB}=1 \%(-9 \%$ to $38 \%)$. The annual total emissions for the whole domain remain unchanged. This shows that the 


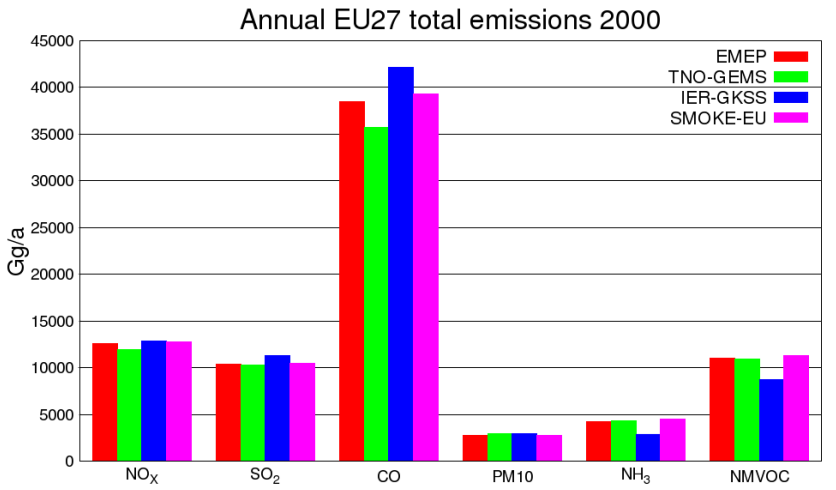

Fig. 4. Comparison of the annual total anthropogenic emissions of different emission datasets for the year 2000. Only emissions from the EU27 in the $54 \times 54 \mathrm{~km}^{2}$ domain (Fig. 2) are taken into account. (The SMOKE-EU dataset also includes $18000 \mathrm{Gg} \mathrm{a}^{-1}$ biogenic NMVOC emissions).

usage of the Modmat module, even for a single SNAP sector, has a significant impact on the calculated air concentrations in certain regions.

\subsection{Comparison of annual total emissions}

First of all, the annual total emissions of the four emission datasets have been compared. The SMOKE-EU, EMEP and IER-GKSS datasets were created for the year 2000 while the TNO-GEMS emissions are for 2003. Figure 4 shows the absolute annual anthropogenic emissions in $\mathrm{Gg} \mathrm{a}^{-1}$ for the EU27. Biogenic emissions, as well as emissions from international shipping, have been excluded from this comparison since they are not included in all datasets. Due to biogenic emissions the total NMVOC emissions in the SMOKE-EU dataset are higher by $18000 \mathrm{Gg} \mathrm{a}^{-1}$. The annual averages of all datasets and their deviations are: $\mathrm{NO}_{\mathrm{x}}(12500 \mathrm{Gg} \pm 6.8 \%), \mathrm{SO}_{2}(10600 \mathrm{Gg} \pm 9.1 \%)$, $\mathrm{CO}(38900 \mathrm{Gg} \pm 16.7 \%), \mathrm{PM}_{10}(2830 \mathrm{Gg} \pm 7.1 \%), \mathrm{NH}_{3}$ $(4000 \mathrm{Gg} \pm 39.8 \%)$, VOC $(10500 \mathrm{Gg} \pm 10 \%)$.

Figure 5 shows that most inventories have annual total emissions similar to those reported by EMEP with differences less than 10\%. Only the IER-GKSS $\mathrm{NH}_{3}$ emissions are 30\% lower than the EMEP values. The SMOKE-EU emissions are somewhat higher than the EMEP reports, since in some countries EPER emissions exceed EMEP emissions. Since the total emissions of the four datasets are similar, no further investigation concerning the aggregated emissions have been made.

\subsection{Comparison of horizontal disaggregation}

All spatial statistics have been calculated using the EU27 emissions only. The values compared are gridded annual

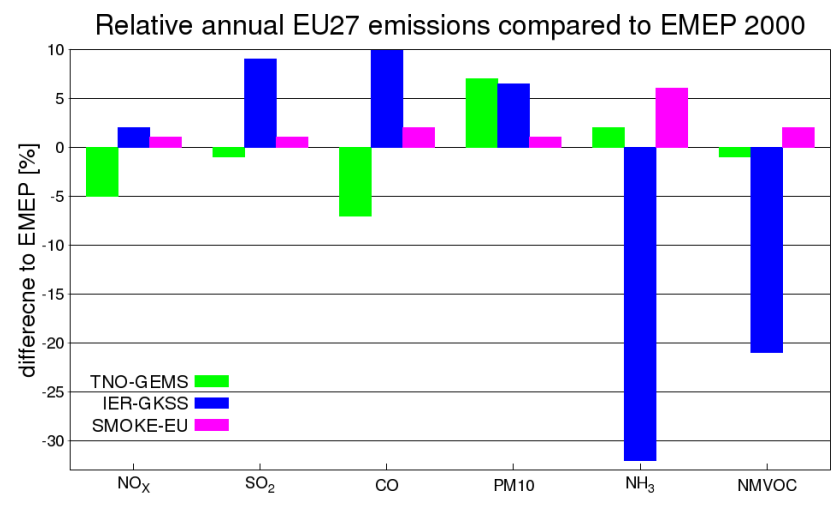

Fig. 5. Annual total emissions of the EU27 (biogenic emissions are not included) relative to those of EMEP. Data for different emission datasets for the year 2000 on a $54 \times 54 \mathrm{~km}^{2}$ domain (Fig. 2).

total emissions for the species $\mathrm{CO}, \mathrm{NO}_{\mathrm{x}}, \mathrm{SO}_{2}, \mathrm{PM}_{10}, \mathrm{NH}_{3}$ and NMVOC. All figures in this section show the best fit (Figs. 6a, 7a, 8a) and the worst fit cases (Figs. 6b, 7b, 8b). Generally $\mathrm{SO}_{2}$ emissions show the best agreement for all four datasets. This is due to the fact that $\mathrm{SO}_{2}$ emissions are well-known concerning the total amount emitted as well as their spatial and temporal distribution. $\mathrm{NH}_{3}$ emissions on the other hand have the highest uncertainties and, thus, generally show the largest differences. Three statistical methods have been chosen in order to compare the spatial disaggregation of the four different emissions datasets:

\subsubsection{The frequency distribution of emissions}

First the frequency distributions of the emissions have been compared. They give an impression of the overall distribution of the emissions, i.e., whether there are more high emission point sources or more low emission areas in a dataset. In general, the distribution of all species is very similar with a strong peak for low values. For most species there is almost no difference in the frequency distribution (Fig. 6). This leads to correlations between 0.8 and 0.99 . Only for $\mathrm{NH}_{3}$ a shift towards lower emission can be seen for the IER-GKSS emissions.

\subsubsection{The frequency distribution of the deviation using EMEP as reference}

The deviations of the annual total emissions for all grid cells have been calculated and plotted as frequency distributions. This statistical measure actually compares the spatial surrogates of the different emission datasets. A shift of all emissions from those of the EMEP dataset by one grid cell, for example, would give high deviations for two identical frequency distributions of emissions. Again 

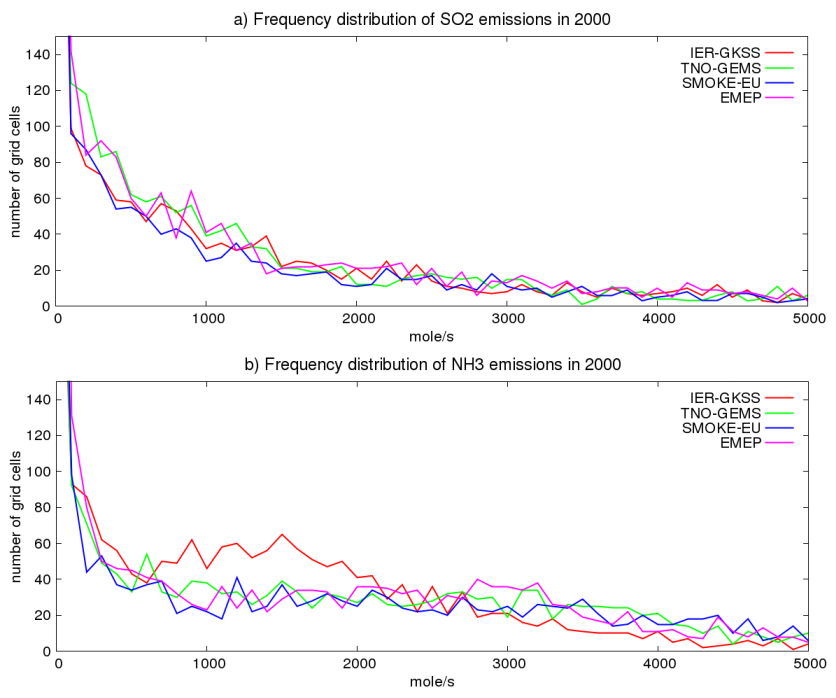

Fig. 6. Frequency distribution of different emission datasets for the year 2000 on a $54 \times 54 \mathrm{~km}^{2}$ domain (Fig. 2). Only emissions of the EU27 are taken into account. (a) $\mathrm{SO}_{2}$ emissions (b) $\mathrm{NH}_{3}$ emissions.

it could be shown that all four datasets are very similar concerning their spatial distribution. As expected the lower $\mathrm{NH}_{3}$ emissions in the IER-GKSS data leads to slight shift towards negative deviations (Fig. 7).

\subsubsection{The spatial variability as indicated by variograms}

As a third measure for the spatial distribution, variograms have been calculated (Eq. 7).

$f(h)=\frac{(z(x+h)-z(x))^{2}}{2}$

where $x=$ reference grid cell; $h=$ distance to origin.

The interval size is $100 \mathrm{~km}$. Since it is not possible to show the variograms for every grid cell, a representative origin has been chosen. The variograms shown here have their origin in a central cell of the EU27. As Eq. (8) indicates the values of a variogram are dependent on the emissions in the origin grid cell. To eliminate the influence of the concentration of the origin grid cell and, therefore, create a more representative comparison, average total emissions have also been calculated. These spatial averages show the annual average concentrations within concentric circles around the origin with $100 \mathrm{~km}$ distance. It can be seen that the spatial distributions as well as the variograms for $\mathrm{SO}_{2}$ follow a similar pattern (Fig. 8). Some differences can still be seen. Looking at the variograms for $\mathrm{SO}_{2}$ it can be seen that the EMEP dataset shows the lowest square differences, which indicates a lower amount of grid cells with much higher emissions than the origin cell. This is most probably due to the lack of point sources in this dataset. The spatial averages show higher $\mathrm{SO}_{2}$ emissions in the $500-700 \mathrm{~km}$
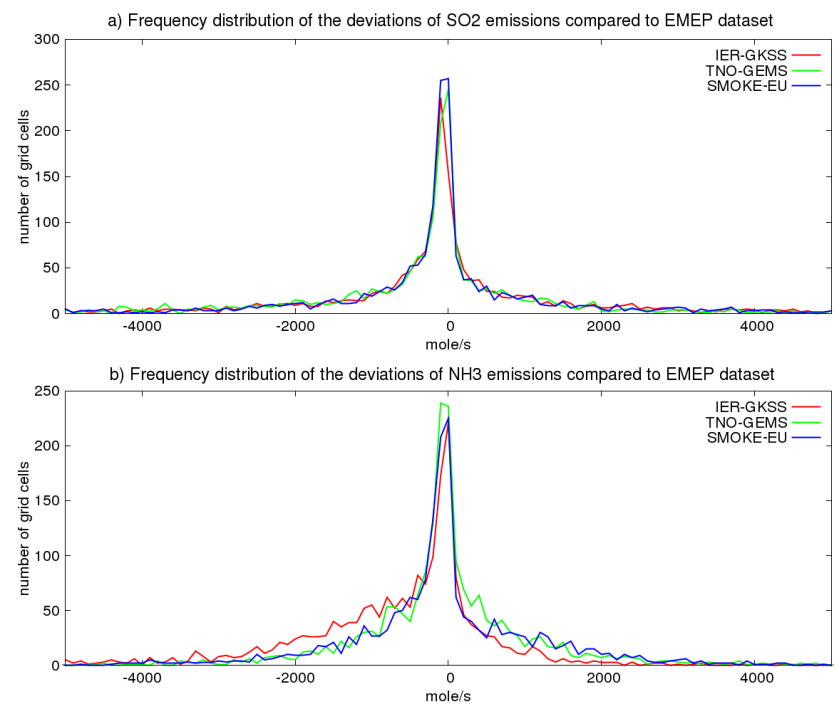

Fig. 7. Frequency distribution of different emission datasets for the year 2000 on a $54 \times 54 \mathrm{~km}^{2}$ domain (Fig. 2). (a) $\mathrm{SO}_{2}$ emissions (b) $\mathrm{NH}_{3}$ emissions.
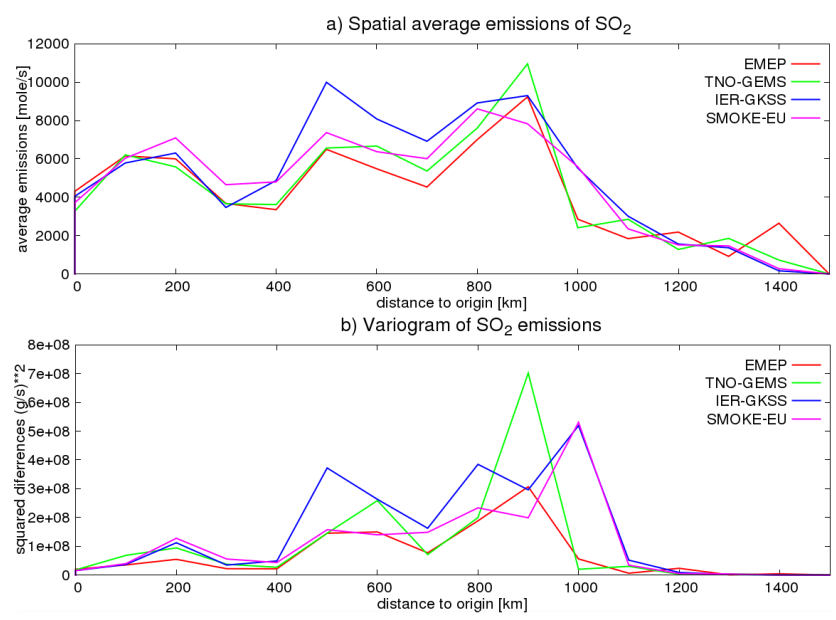

Fig. 8. (a) Spatial average annual $\mathrm{SO}_{2}$ emissions of different emission datasets for the year 2000. (b) Variograms for $\mathrm{SO}_{2}$ emissions of different emission datasets for the year 2000. All values are for concentric circles with a $100 \mathrm{~km}$ distance on a $54 \times 54 \mathrm{~km}^{2}$ domain (Fig. 2).

circles (30-40\%) for the IER-GKSS datasets. This indicates that the $\sim 8 \%$ higher total $\mathrm{SO}_{2}$ emissions in this dataset are due to higher emissions in a certain area rather than a general overestimation (Fig. 4).

$\mathrm{NH}_{3}$ shows the largest differences with a much higher squared difference in the $600 \mathrm{~km}$ and $900 \mathrm{~km}$ circles for the SMOKE-EU emissions, while the spatial averages show only slightly higher $\mathrm{NH}_{3}$ emissions in these areas of the SMOKE-EU dataset (Fig. 9). This could be due to a stronger partitioning of high and low emission grid cells in 
a) Spatial average emissions of $\mathrm{NH}_{3}$
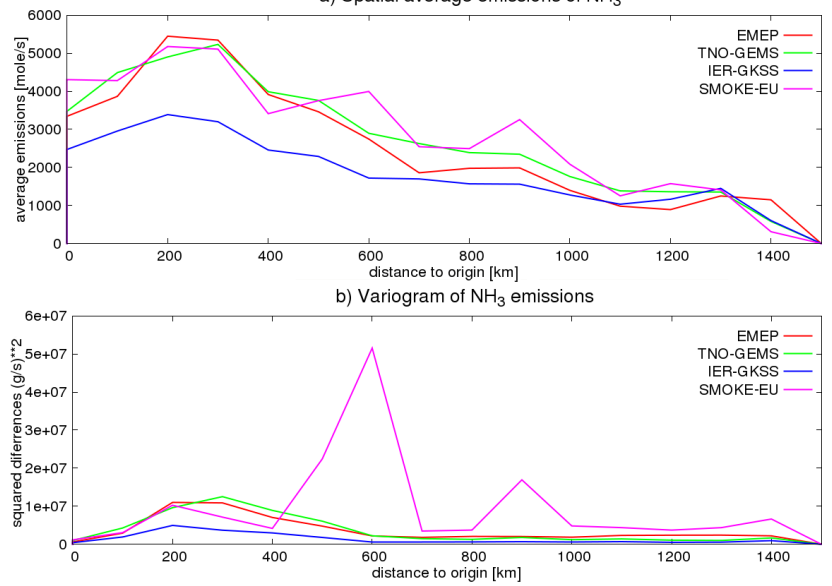

Fig. 9. (a) Spatial average annual $\mathrm{NH}_{3}$ emissions of different emission datasets for the year 2000. (b) Variograms for $\mathrm{NH}_{3}$ of different emission datasets for the year 2000. All values are for concentric circles with $100 \mathrm{~km}$ distance on a $54 \times 54 \mathrm{~km}^{2}$ domain (Fig. 2).

this area. A possible reason is the spatial disaggregation by EUROSTAT NUTS2 statistics. The IER-GKSS dataset shows lower emissions of $\mathrm{NH}_{3}$ throughout the domain compared to the other datasets.

\subsection{Temporal distribution}

Temporal profiles were available for the SMOKE-EU, IERGKSS and the TNO-GEMS emissions. These temporal profiles are not directly comparable. The SMOKE profiles are available for each SNAP sector, the original IER-GKSS profiles are not available and the TNO-GEMS profiles are available for each region and species. In order to gain comparable temporal profiles for all three datasets, the average emissions for all grid cells of the EU27 were used to create species-dependent temporal profiles with daily resolution.

For most species these annual time series show deviations of less than $20 \%$ for all 365 daily temporal factors. Figure 10 shows an example plot for NO. The biogenic NO emissions, which occur mainly during summer, lead to a slightly different temporal profiles in the SMOKE-EU dataset (Fig. 10a). Temporal profiles of $\mathrm{NO}_{\mathrm{x}}, \mathrm{PM}_{10}$ and $\mathrm{CO}$ are similar. The highest deviations were found for $\mathrm{NH}_{3}$ (Fig. 10b). Here the large, sudden changes between months of the original SMOKE temporal disaggregation can be seen.

\subsection{Vertical distribution}

The vertical distributions of the SMOKE-EU emissions were compared to the EMEP vertical distributions. For this purpose, annual average vertical profiles for each species
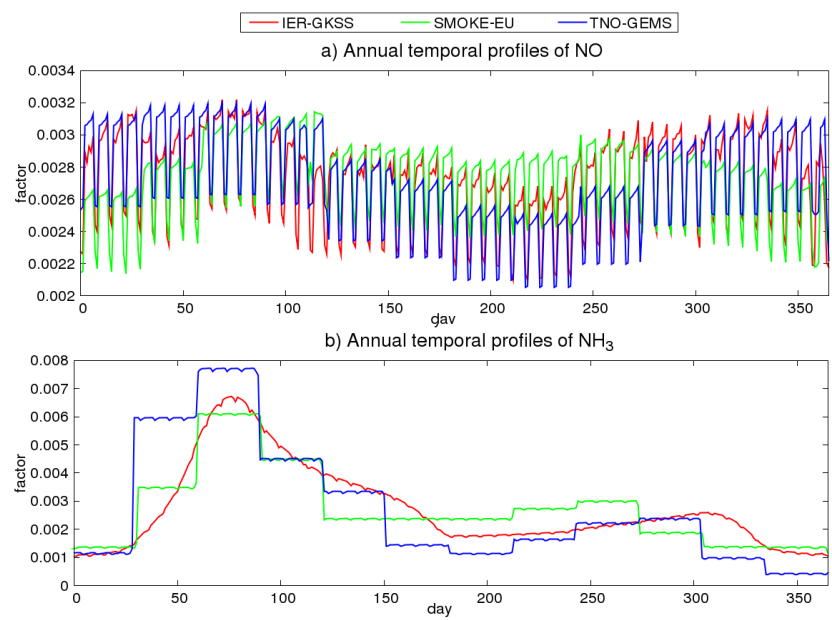

Fig. 10. Averaged annual temporal profiles with daily resolution of different emission datasets for the year 2000 on a $54 \times 54 \mathrm{~km}^{2}$ domain (Fig. 2). (a) $\mathrm{NO}$ emissions (b) $\mathrm{NH}_{3}$ emissions. The biogenic NO emissions included in the SMOKE-EU dataset lead to higher average emissions in summer and lower average emissions in winter.
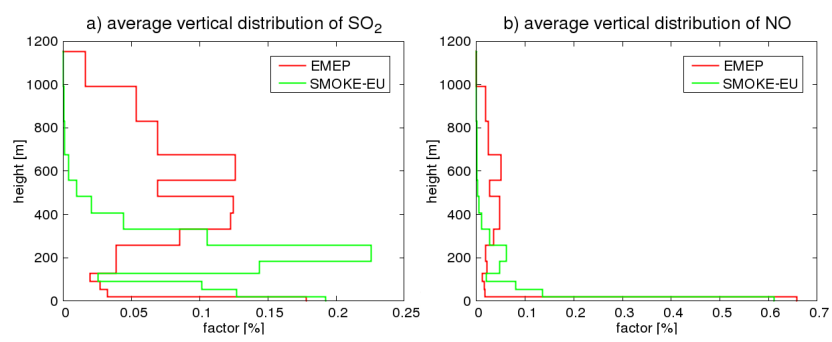

Fig. 11. Average vertical distribution of different emission datasets for the year 2000. (a) $\mathrm{SO}_{2}$ emissions (b) $\mathrm{NO}$ emissions. For comparison with the SMOKE-EU dataset, the official EMEP vertical profiles were interpolated from 6 to 30 layers. The TNOGEMS dataset uses the EMEP vertical distributions. All values are averages over a $54 \times 54 \mathrm{~km}^{2}$ domain (Fig. 2).

were calculated. Also the 5 emission layers of the EMEP profile were interpolated to the 30 layers of the SMOKEEU dataset. As in Sect. 3.5, this does not necessarily represent the actual profiles used by the emission models. In Fig. 11, it can be seen that the SMOKE-EU plume rise calculations result in lower emission heights than the official EMEP vertical distribution. EMEP distinguishes 10 static vertical profiles, one for each SNAP sector. The SMOKE-EU effective emission heights are determined using temperature, pressure and wind dependent plume rise calculations, thus, leading to different emission heights for each source throughout the year. For some species EMEP uses large emissions in high layers $\left(\mathrm{SO}_{\mathrm{x}}\right.$ : 400-600 m 30\% $>600 \mathrm{~m} \mathrm{20 \%})\left(\mathrm{NO}_{\mathrm{x}}: 400-800 \mathrm{~m} \mathrm{10 \%}\right)$. The SMOKE-EU plume rise calculations show almost no emissions higher than $600 \mathrm{~m}$ with less than $10 \%$ above $400 \mathrm{~m}$. 


\section{Comparison of CTM calculated concentrations to observations}

The CTM CMAQ4.6 of the US EPA (US EPA, 2009) was used to simulate atmospheric concentrations of air pollutants for the year 2000. Figure 2 shows the modelling domain containing Europe and the surrounding countries. The spatial resolution is $54 \times 54 \mathrm{~km}^{2}$ with 30 vertical layers, the photochemical mechanism used is CB-IV. Meteorological fields are taken from the COSMO-CLM model (Rockel and Geyer, 2008; Rockel et al., 2008). Monthly average boundary conditions were derived from the MOZART global model (Horowitz et al., 2003; Niemeier et al., 2006). With this setup, four CMAQ runs using different emission datasets were calculated. The three emission datasets for comparison with SMOKE-EU have been used as described in Sect. 3.1. Additionally, VOC and PM emissions were split using the same distribution as SMOKE-EU. SMOKE-EU is the only one among these datasets which takes into account biogenic emissions.

The calculated atmospheric concentrations in the lowest model layer were compared with observations from EMEP measurement stations. From 242 available rural measurement stations those with more than $90 \%$ data coverage for the year 2000 were used for comparison. Mountain stations which are not representative for a model grid cell have been excluded (e.g., CH01 Jungfraujoch at $3573 \mathrm{~m}$ ). Six different compounds are used for comparison, three gaseous species $\left(\mathrm{NO}_{2} \mathrm{SO}_{2}, \mathrm{O}_{3}\right)$ and three aerosol components $\left(\mathrm{SO}_{4}^{2-}, \mathrm{NH}_{4}^{+}, \mathrm{NO}_{3}^{-}\right)$. Ozone concentrations are given as hourly values while all other values are reported as daily averages. Table 4 shows all used EMEP measurement sites and provides information on their location and the species observed. Figure 12 depicts a map of all measurement stations. Some sites consistently disagree with modelled values for all species and emission models (e.g., IT04 Ispra). This may be caused by strong topographic gradients not resolved by the CTM, the meteorological model, local sources influencing the station or for instrumental reasons. It should be kept in mind that a single observation site is not necessarily representative for the average concentrations in a $54 \times 54 \mathrm{~km}^{2}$ grid cell with a height of the lowest layer of $36 \mathrm{~m}$.

The statistical measures used for comparison of simulated and observed values were selected based on those suggested by Schlünzen and Sokhi (2009) and are described in further detail in Appendix B. Table 5 provides statistical values averaged over all relevant measurement stations as well as their standard deviation. The general picture when comparing the CMAQ results with measurements is that the four emission datasets produce comparable concentrations for all species.

The SMOKE-EU and EMEP based CTM runs predict slightly higher ozone values than the other models (Fig. 13a). One reason for this is the implementation of biogenic

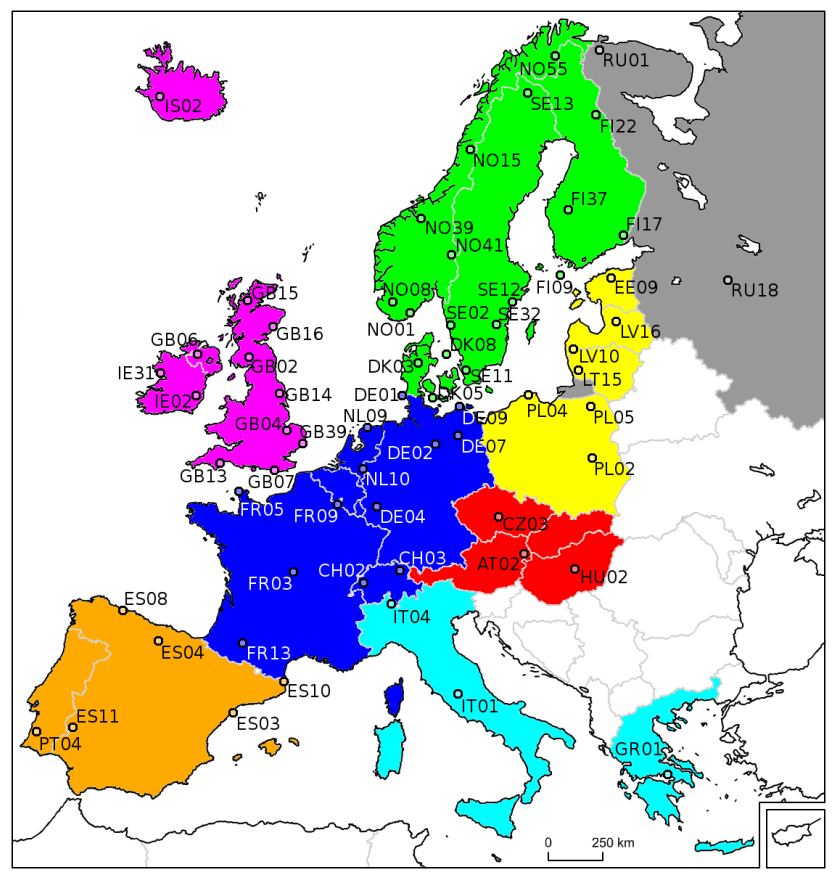

Fig. 12. Map indicating the location of EMEP measurement stations used for comparison with simulated air concentrations (Table 4). The coloured areas are geographical regions used for regional analysis in Fig. 15. Yellow: Estonia (EE), Lithuania (LT), Latvia (LV), Poland (PL). Orange: Spain (ES), Portugal (PT). Red: Austria (AT), Czech Republic (CZ), Hungary (HU), Slovakia (SK). Pink: Ireland (IE), Iceland (IS), Great Britain (GB). Turquoise: Italy (IT), Greece (GR). Green: Denmark (DK), Finland (FI), Norway (NO), Sweden (SE). Blue: Belgium (BE), Switzerland $(\mathrm{CH})$, Germany (DE), France (FR), Luxembourg (LU), Netherlands (NL). Grey: Russia (RU).

emissions in SMOKE-EU, leading to higher VOC and NO emissions during summer. Also the vertical distribution of $\mathrm{NO}_{\mathrm{x}}$ emissions in the SMOKE-EU and EMEP datasets potentially changes the ozone regime, in certain regions, from VOC limited to $\mathrm{NO}_{\mathrm{x}}$ limited (Fig. 11b). However, since $\mathrm{O}_{3}$ is strongly influenced by the meteorology (Andersson and Langner, 2005), the correlations and factor of 2 (F2) percentages for all four emission datasets are almost identical (Fig. 13c, Table 5). Only the Index of Agreement (IOA) for the SMOKE-EU scenario is slightly higher (Fig. 13b). The diagram in Fig. 15a presents a similar picture. Although some regional differences can be seen, most measurement stations form a tight cluster between correlations of 0.5 and 0.8 . The ozone concentrations, calculated by CMAQ, are generally $10 \%$ higher than those observed. Test runs with meteorological fields created with a different meteorological model (MM5) (Matthias et al., 2009) produced 20\% lower $\mathrm{O}_{3}$ concentrations.

Considering the Sulfuroxide species the highest daily mean $\mathrm{SO}_{4}^{2-}$ concentrations are predicted when using the SMOKE-EU dataset (Mean $=0.66 \mu \mathrm{g} \mathrm{m}^{-3}$ ) followed by the EMEP case with $0.61 \mu \mathrm{g} \mathrm{S} \mathrm{m}{ }^{-3}$ while the other two 
Table 4. EMEP measurement stations for the year 2000 used for comparison with modelled air concentrations. All station locations are depicted in Fig. 12.

\begin{tabular}{|c|c|c|c|c|c|c|c|c|c|}
\hline ID & Name & Longitude & Latitude & $\begin{array}{c}\text { Altitude } \\
{[\mathrm{m}]}\end{array}$ & $\mathrm{O}_{3}$ & $\mathrm{NO}_{2}$ & $\mathrm{SO}_{2}$ & $\mathrm{SO}_{4}$ & $\mathrm{NO}_{3}$ \\
\hline AT02R & Illmitz & $47^{\circ} 46^{\prime} 0^{\prime \prime} \mathrm{N}$ & $16^{\circ} 46^{\prime} 0^{\prime \prime} \mathrm{E}$ & 117 & $\mathrm{X}$ & $\mathrm{X}$ & $X$ & $X$ & \\
\hline $\mathrm{CH} 02 \mathrm{R}$ & Payerne & $46^{\circ} 48^{\prime} 47^{\prime \prime} \mathrm{N}$ & $6^{\circ} 56^{\prime} 41^{\prime \prime} \mathrm{E}$ & 489 & $\mathrm{X}$ & $X$ & $\mathrm{X}$ & $\mathrm{X}$ & \\
\hline CH03R & Tänikon & $47^{\circ} 28^{\prime} 47^{\prime \prime} \mathrm{N}$ & $8^{\circ} 54^{\prime} 17^{\prime \prime} \mathrm{E}$ & 539 & $X$ & $X$ & & & \\
\hline CZ03R & Kosetice & $49^{\circ} 35^{\prime} 0^{\prime \prime} \mathrm{N}$ & $15^{\circ} 5^{\prime} 0^{\prime \prime} \mathrm{E}$ & 534 & $X$ & & & & \\
\hline DE01R & Westerland & $54^{\circ} 55^{\prime} 32^{\prime \prime} \mathrm{N}$ & $8^{\circ} 18^{\prime} 35^{\prime \prime} \mathrm{E}$ & 12 & $X$ & $X$ & & & \\
\hline DE02R & Langenbrügge & $52^{\circ} 48^{\prime} 8^{\prime \prime} \mathrm{N}$ & $10^{\circ} 45^{\prime} 34^{\prime \prime} \mathrm{E}$ & 74 & $\mathrm{X}$ & $\mathrm{X}$ & & & \\
\hline DE04R & Deuselbach & $49^{\circ} 45^{\prime} 53^{\prime \prime} \mathrm{N}$ & $7^{\circ} 3^{\prime} 7^{\prime \prime} \mathrm{E}$ & 480 & $X$ & & & & \\
\hline DE07R & Neuglobsow & $53^{\circ} 10^{\prime} 0^{\prime \prime} \mathrm{N}$ & $13^{\circ} 2^{\prime} 0^{\prime \prime} \mathrm{E}$ & 62 & $X$ & $X$ & $X$ & $X$ & \\
\hline DE09R & Zingst & $54^{\circ} 26^{\prime} 0^{\prime \prime} \mathrm{N}$ & $12^{\circ} 44^{\prime} 0^{\prime \prime} \mathrm{E}$ & 1 & $X$ & $X$ & $X$ & $\mathrm{X}$ & \\
\hline DK03R & Tange & $56^{\circ} 21^{\prime} 0^{\prime \prime} \mathrm{N}$ & $9^{\circ} 36^{\prime} 0^{\prime \prime} \mathrm{E}$ & 13 & & & $X$ & $\mathrm{X}$ & \\
\hline DK05R & Keldsnor & $54^{\circ} 44^{\prime} 0^{\prime \prime} \mathrm{N}$ & $10^{\circ} 44^{\prime} 0^{\prime \prime} \mathrm{E}$ & 10 & & & $X$ & $\mathrm{X}$ & \\
\hline DK08R & Anholt & $56^{\circ} 43^{\prime} 0^{\prime \prime} \mathrm{N}$ & $11^{\circ} 31^{\prime} 0^{\prime \prime} \mathrm{E}$ & 40 & & $\mathrm{X}$ & $X$ & $\mathrm{X}$ & \\
\hline EE09R & Lahemaa & $59^{\circ} 30^{\prime} 0^{\prime \prime} \mathrm{N}$ & $25^{\circ} 54^{\prime} 0^{\prime \prime} \mathrm{E}$ & 32 & & $X$ & & $\mathrm{X}$ & \\
\hline ES03R & Roquetas & $40^{\circ} 49^{\prime} 14^{\prime \prime} \mathrm{N}$ & $0^{\circ} 29^{\prime} 29^{\prime \prime} \mathrm{E}$ & 44 & & $X$ & $X$ & $X$ & $X$ \\
\hline ES04R & Logroño & $42^{\circ} 27^{\prime} 28^{\prime \prime} \mathrm{N}$ & $2^{\circ} 30^{\prime} 11^{\prime \prime} \mathrm{W}$ & 445 & & $X$ & $X$ & $\mathrm{X}$ & $\mathrm{X}$ \\
\hline ES08R & Niembro & $43^{\circ} 26^{\prime} 32^{\prime \prime} \mathrm{N}$ & $4^{\circ} 51^{\prime} 1^{\prime \prime} \mathrm{W}$ & 134 & & $X$ & $X$ & & $\mathrm{X}$ \\
\hline ES10R & Cabo de Creus & $42^{\circ} 19^{\prime} 10^{\prime \prime} \mathrm{N}$ & $3^{\circ} 19^{\prime} 1^{\prime \prime} \mathrm{E}$ & 23 & & & $X$ & $\mathrm{X}$ & $\mathrm{X}$ \\
\hline ES11R & Barcarrola & $38^{\circ} 28^{\prime} 33^{\prime \prime} \mathrm{N}$ & $6^{\circ} 55^{\prime} 22^{\prime \prime} \mathrm{W}$ & 393 & $\mathrm{X}$ & & $X$ & $\mathrm{X}$ & $X$ \\
\hline FI09R & Utö & $59^{\circ} 46^{\prime} 45^{\prime \prime} \mathrm{N}$ & $21^{\circ} 22^{\prime} 38^{\prime \prime} \mathrm{E}$ & 7 & $\mathrm{X}$ & & $\mathrm{X}$ & $\mathrm{X}$ & \\
\hline FI17R & Virolahti II & $60^{\circ} 31^{\prime} 36^{\prime \prime} \mathrm{N}$ & $27^{\circ} 41^{\prime} 10^{\prime \prime} \mathrm{E}$ & 4 & $X$ & & $X$ & $\mathrm{X}$ & \\
\hline FI22R & Oulanka & $66^{\circ} 19^{\prime} 13^{\prime \prime} \mathrm{N}$ & $29^{\circ} 24^{\prime} 6^{\prime \prime} \mathrm{E}$ & 310 & $\mathrm{X}$ & & $X$ & $\mathrm{X}$ & \\
\hline FI37R & Ahtari II & $62^{\circ} 35^{\prime} 0^{\prime \prime} \mathrm{N}$ & $24^{\circ} 11^{\prime} 0^{\prime \prime} \mathrm{E}$ & 180 & & & $X$ & $\mathrm{X}$ & \\
\hline FR03R & La Crouzille & $45^{\circ} 50^{\prime} \mathrm{N}$ & $1^{\circ} 16^{\prime} 0^{\prime \prime} \mathrm{E}$ & 497 & & & & $\mathrm{X}$ & \\
\hline FR05R & La Hague & $49^{\circ} 37^{\prime} 0^{\prime \prime} \mathrm{N}$ & $1^{\circ} 49^{\prime} 59^{\prime \prime} \mathrm{W}$ & 133 & & & & $\mathrm{X}$ & \\
\hline FR09R & Revin & $49^{\circ} 54^{\prime} 0^{\prime \prime} \mathrm{N}$ & $4^{\circ} 38^{\prime} 0^{\prime \prime} \mathrm{E}$ & 390 & $X$ & & $X$ & $\mathrm{X}$ & \\
\hline FR13R & Peyrusse Vieille & $43^{\circ} 37^{\prime} 0^{\prime \prime} \mathrm{N}$ & $0^{\circ} 11^{\prime} 0^{\prime \prime} \mathrm{E}$ & 2 & & & $X$ & $\mathrm{X}$ & \\
\hline GB02R & Eskdalemuir & $55^{\circ} 18^{\prime} 47^{\prime \prime} \mathrm{N}$ & $3^{\circ} 12^{\prime} 15^{\prime \prime} \mathrm{W}$ & 243 & $\mathrm{X}$ & & & & \\
\hline GB04R & Stoke Ferry & $52^{\circ} 34^{\prime} 0^{\prime \prime} \mathrm{N}$ & $0^{\circ} 30^{\prime} 0^{\prime \prime} \mathrm{E}$ & 15 & & & & $\mathrm{X}$ & \\
\hline GB06R & Lough Navar & $54^{\circ} 26^{\prime} 35^{\prime \prime} \mathrm{N}$ & $7^{\circ} 52^{\prime} 12^{\prime \prime} \mathrm{W}$ & 126 & & & & $\mathrm{X}$ & \\
\hline GB07R & Barcombe Mills & $50^{\circ} 52^{\prime} 0^{\prime \prime} \mathrm{N}$ & $0^{\circ} 1^{\prime} 59^{\prime \prime} \mathrm{W}$ & 8 & & & & $\mathrm{X}$ & \\
\hline GB13R & Yarner Wood & $50^{\circ} 35^{\prime} 47^{\prime \prime} \mathrm{N}$ & $3^{\circ} 42^{\prime} 47^{\prime \prime} \mathrm{W}$ & 119 & & & & $\mathrm{X}$ & \\
\hline GB14R & High Muffles & $54^{\circ} 20^{\prime} 4^{\prime \prime} \mathrm{N}$ & $0^{\circ} 48^{\prime} 27^{\prime \prime} \mathrm{W}$ & 267 & $X$ & & $\mathrm{X}$ & $\mathrm{X}$ & \\
\hline GB15R & Strath Vaich Dam & $57^{\circ} 44^{\prime} 4^{\prime \prime} \mathrm{N}$ & $4^{\circ} 46^{\prime} 28^{\prime \prime} \mathrm{W}$ & 270 & $\mathrm{X}$ & & & $\mathrm{X}$ & \\
\hline GB16R & Glen Dye & $56^{\circ} 58^{\prime} 0^{\prime \prime} \mathrm{N}$ & $2^{\circ} 25^{\prime} 0^{\prime \prime} \mathrm{W}$ & 85 & & & & $\mathrm{X}$ & \\
\hline GB39R & Sibton & $52^{\circ} 17^{\prime} 38^{\prime \prime} \mathrm{N}$ & $1^{\circ} 27^{\prime} 47^{\prime \prime} \mathrm{E}$ & 46 & $\mathrm{X}$ & & & & \\
\hline GR01R & Aliartos & $38^{\circ} 22^{\prime} 0^{\prime \prime} \mathrm{N}$ & $23^{\circ} 5^{\prime} 0^{\prime \prime} \mathrm{E}$ & 110 & & $\mathrm{X}$ & & & \\
\hline HU02R & K-puszta & $46^{\circ} 58^{\prime} 0^{\prime \prime} \mathrm{N}$ & $19^{\circ} 35^{\prime} 0^{\prime \prime} \mathrm{E}$ & 125 & $X$ & $X$ & $X$ & $\mathrm{X}$ & $\mathrm{X}$ \\
\hline IE02R & Turlough Hill & $53^{\circ} 2^{\prime} 12^{\prime \prime} \mathrm{N}$ & $6^{\circ} 24^{\prime} 0^{\prime \prime} \mathrm{W}$ & 420 & & & & $X$ & \\
\hline IE31R & Mace Head & $53^{\circ} 10^{\prime} 0^{\prime \prime} \mathrm{N}$ & $9^{\circ} 30^{\prime} 0^{\prime \prime} \mathrm{W}$ & 15 & $\mathrm{X}$ & & & & \\
\hline IS02R & Irafoss & $64^{\circ} 5^{\prime} 0^{\prime \prime} \mathrm{N}$ & $21^{\circ} 1^{\prime} 0^{\prime \prime} \mathrm{W}$ & 66 & & & & $\mathrm{X}$ & \\
\hline IT01R & Montelibretti & $42^{\circ} 6^{\prime} 0^{\prime \prime} \mathrm{N}$ & $12^{\circ} 38^{\prime} 0^{\prime \prime} \mathrm{E}$ & 48 & $X$ & $X$ & & $\mathrm{X}$ & $\mathrm{X}$ \\
\hline IT04R & Ispra & $45^{\circ} 48^{\prime} 0^{\prime \prime} \mathrm{N}$ & $8^{\circ} 38^{\prime} 0^{\prime \prime} \mathrm{E}$ & 209 & $X$ & $X$ & $X$ & $\mathrm{X}$ & $X$ \\
\hline LT15R & Preila & $55^{\circ} 21^{\prime} 0^{\prime \prime} \mathrm{N}$ & $21^{\circ} 4^{\prime} 0^{\prime \prime} \mathrm{E}$ & 5 & $\mathrm{X}$ & $X$ & $\mathrm{X}$ & $\mathrm{X}$ & \\
\hline LV10R & Rucava & $56^{\circ} 13^{\prime} 0^{\prime \prime} \mathrm{N}$ & $21^{\circ} 13^{\prime} 0^{\prime \prime} \mathrm{E}$ & 5 & $\mathrm{X}$ & $X$ & $X$ & $\mathrm{X}$ & $\mathrm{X}$ \\
\hline LV16R & Zoseni & $57^{\circ} 8^{\prime} 0^{\prime \prime} \mathrm{N}$ & $25^{\circ} 55^{\prime} 0^{\prime \prime} \mathrm{E}$ & 183 & & $X$ & $\mathrm{X}$ & $\mathrm{X}$ & $\mathrm{X}$ \\
\hline NL09R & Kollumerwaard & $53^{\circ} 20^{\prime} 2^{\prime \prime} \mathrm{N}$ & $6^{\circ} 16^{\prime} 38^{\prime \prime} \mathrm{E}$ & 1 & $X$ & $X$ & & $\mathrm{X}$ & $X$ \\
\hline NL10R & Vredepeel & $51^{\circ} 32^{\prime} 28^{\prime \prime} \mathrm{N}$ & $5^{\circ} 51^{\prime} 13^{\prime \prime} \mathrm{E}$ & 28 & & $\mathrm{X}$ & & $\mathrm{X}$ & $\mathrm{X}$ \\
\hline NO01R & Birkenes & $58^{\circ} 23^{\prime} 0^{\prime \prime} \mathrm{N}$ & $8^{\circ} 15^{\prime} 0^{\prime \prime} \mathrm{E}$ & 190 & $\mathrm{X}$ & $\mathrm{X}$ & $X$ & $\mathrm{X}$ & $\mathrm{X}$ \\
\hline NO08R & Skreådalen & $58^{\circ} 49^{\prime} 0^{\prime \prime} \mathrm{N}$ & $6^{\circ} 43^{\prime} 0^{\prime \prime} \mathrm{E}$ & 475 & & $X$ & $X$ & $\mathrm{X}$ & $X$ \\
\hline NO15R & Tustervatn & $65^{\circ} 50^{\prime} 0^{\prime \prime} \mathrm{N}$ & $13^{\circ} 55^{\prime} 0^{\prime \prime} \mathrm{E}$ & 439 & & $X$ & $X$ & $X$ & $\mathrm{X}$ \\
\hline NO39R & Kårvatn & $62^{\circ} 47^{\prime} 0^{\prime \prime} \mathrm{N}$ & $8^{\circ} 53^{\prime} 0^{\prime \prime} \mathrm{E}$ & 210 & & $X$ & $X$ & $\mathrm{X}$ & $X$ \\
\hline NO41R & Osen & $61^{\circ} 15^{\prime} 0^{\prime \prime} \mathrm{N}$ & $11^{\circ} 47^{\prime} 0^{\prime \prime} \mathrm{E}$ & 440 & & $X$ & $X$ & $\mathrm{X}$ & $\mathrm{X}$ \\
\hline $\mathrm{NO} 42 \mathrm{G}$ & Spitsbergen, Zeppelinfjell & $78^{\circ} 54^{\prime} 0^{\prime \prime} \mathrm{N}$ & $11^{\circ} 53^{\prime} 0^{\prime \prime} \mathrm{E}$ & 474 & & & $\mathrm{X}$ & $\mathrm{X}$ & $\mathrm{X}$ \\
\hline NO55R & Karasjok & $69^{\circ} 28^{\prime} 0^{\prime \prime} \mathrm{N}$ & $25^{\circ} 13^{\prime} 0^{\prime \prime} \mathrm{E}$ & 333 & $\mathrm{X}$ & $\mathrm{X}$ & $\mathrm{X}$ & $\mathrm{X}$ & $\mathrm{X}$ \\
\hline
\end{tabular}


Table 4. Continued.

\begin{tabular}{llrrrrrrrr}
\hline ID & Name & Longitude & Latitude & $\begin{array}{c}\text { Altitude } \\
{[\mathrm{m}]}\end{array}$ & $\mathrm{O}_{3}$ & $\mathrm{NO}_{2}$ & $\mathrm{SO}_{2}$ & $\mathrm{SO}_{4}$ & $\mathrm{NO}_{3}$ \\
\hline PL02R & Jarczew & $51^{\circ} 49^{\prime} 0^{\prime \prime} \mathrm{N}$ & $21^{\circ} 59^{\prime} 0^{\prime \prime} \mathrm{E}$ & 180 & $\mathrm{X}$ & $\mathrm{X}$ & $\mathrm{X}$ & $\mathrm{X}$ & $\mathrm{X}$ \\
PL04R & Leba & $54^{\circ} 45^{\prime} 0^{\prime \prime} \mathrm{N}$ & $17^{\circ} 32^{\prime} 0^{\prime \prime} \mathrm{E}$ & 2 & $\mathrm{X}$ & $\mathrm{X}$ & $\mathrm{X}$ & $\mathrm{X}$ & $\mathrm{X}$ \\
PL05R & Diabla Gora & $54^{\circ} 9^{\prime} 0^{\prime \prime} \mathrm{N}$ & $22^{\circ} 4^{\prime} 0^{\prime \prime} \mathrm{E}$ & 157 & & $\mathrm{X}$ & $\mathrm{X}$ & $\mathrm{X}$ & \\
PT04R & Monte Velho & $38^{\circ} 5^{\prime} 0^{\prime \prime} \mathrm{N}$ & $8^{\circ} 48^{\prime} 0^{\prime \prime} \mathrm{W}$ & 43 & $\mathrm{X}$ & & & & \\
RU01R & Janiskoski & $68^{\circ} 56^{\prime} 0^{\prime \prime} \mathrm{N}$ & $28^{\circ} 51^{\prime} 0^{\prime \prime} \mathrm{E}$ & 118 & & & $\mathrm{X}$ & $\mathrm{X}$ & $\mathrm{X}$ \\
RU18R & Danki & $54^{\circ} 54^{\prime} 0^{\prime \prime} \mathrm{N}$ & $37^{\circ} 48^{\prime} 0^{\prime \prime} \mathrm{E}$ & 150 & $\mathrm{X}$ & & & $\mathrm{X}$ & $\mathrm{X}$ \\
SE02R & Rörvik & $57^{\circ} 25^{\prime} 0^{\prime \prime} \mathrm{N}$ & $11^{\circ} 56^{\prime} 0^{\prime \prime} \mathrm{E}$ & 10 & $\mathrm{X}$ & $\mathrm{X}$ & $\mathrm{X}$ & $\mathrm{X}$ & \\
SE11R & Vavihill & $56^{\circ} 1^{\prime} 0^{\prime \prime} \mathrm{N}$ & $13^{\circ} 9^{\prime} 0^{\prime \prime} \mathrm{E}$ & 175 & $\mathrm{X}$ & & & & \\
SE12R & Aspvreten & $58^{\circ} 48^{\prime} 0^{\prime \prime} \mathrm{N}$ & $17^{\circ} 23^{\prime} 0^{\prime \prime} \mathrm{E}$ & 20 & $\mathrm{X}$ & & & & \\
SE13R & Esrange & $67^{\circ} 53^{\prime} 0^{\prime \prime} \mathrm{N}$ & $21^{\circ} 4^{\prime} 0^{\prime \prime} \mathrm{E}$ & 475 & $\mathrm{X}$ & & & & \\
SE32R & Norra-Kvill & $57^{\circ} 49^{\prime} 0^{\prime \prime} \mathrm{N}$ & $15^{\circ} 34^{\prime} 0^{\prime \prime} \mathrm{E}$ & 261 & $\mathrm{X}$ & & & & \\
\hline
\end{tabular}
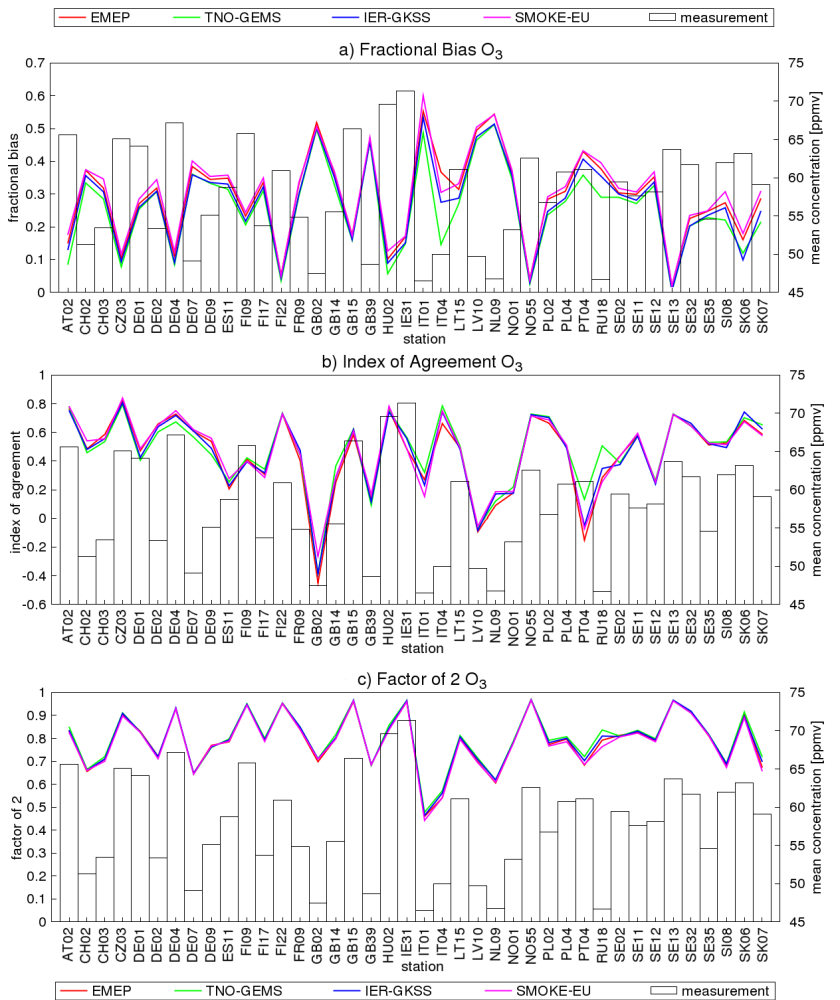

Fig. 13. Comparison of modelled $\mathrm{O}_{3}$ concentrations using four different emission datasets with hourly observations from 40 rural EMEP measurement sites $(N=329197)$ for the year 2000 (see also Tables 6 and 7). (a) Fractional bias (b) index of agreement (c) relative amount of values within a factor of $2(1=100 \%)$.

datasets lead to an underestimation of $\mathrm{SO}_{4}^{2-}$ (Mean $=0.57$ and $0.54 \mu \mathrm{g} \mathrm{S} \mathrm{m}^{-3}$ ) (Fig. 14 and Table 5). Similar results can be seen for $\mathrm{SO}_{2}$ where higher values are simulated in the SMOKE-EU case compared to the CTM runs using the other three emission datasets (Table 5). Since the total
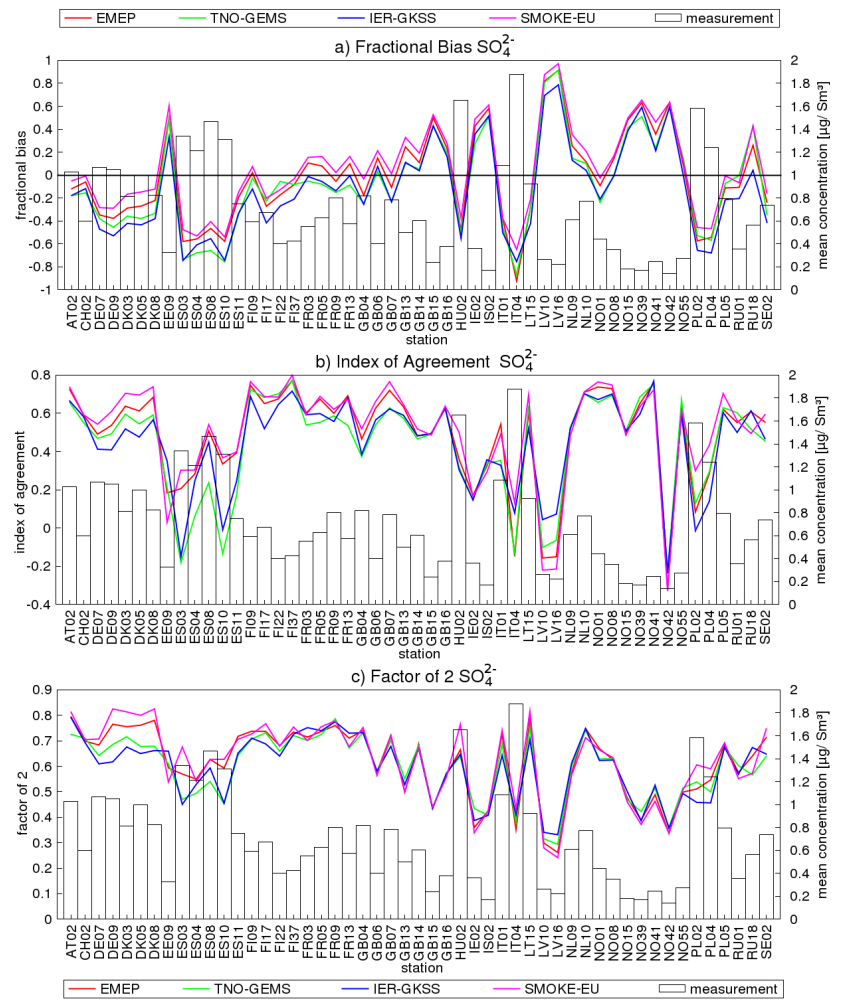

Fig. 14. Comparison of modelled $\mathrm{SO}_{4}^{2-}$ concentrations using four different emission datasets with daily mean observations from 51 rural EMEP measurement sites $(N=17536)$ for the year 2000 (see also Tables 6 and 7). (a) Fractional bias (b) index of agreement (c) relative amount of values within a factor of $2(1=100 \%)$.

emissions as well as the spatial and temporal distribution of the $\mathrm{SO}_{2}$ emissions are very similar in all four datasets, these differences may be explained by different vertical distributions. In the EMEP and the TNO-GEMS datasets $\mathrm{SO}_{2}$ is emitted in higher altitudes and partially above 
Table 5. Statistical comparison of CMAQ results using four different emission datasets. Values are averages over all measurement stations and their standard deviations. For more detailed results, see Figs. 13-16.

\begin{tabular}{|c|c|c|c|c|c|}
\hline & EMEP & TNO-GEMS & IER-GKSS & SMOKE-EU & OBSERVATION \\
\hline \multicolumn{6}{|c|}{$\mathrm{O}_{3}-40$ Stations $(N=329197)$} \\
\hline MEAN & $77.43 \pm 6.05$ & $74.58 \pm 6.26$ & $75.86 \pm 6.08$ & $78.25 \pm 6.44$ & $57.79 \pm 6.76$ \\
\hline FB & $0.29 \pm 0.13$ & $0.26 \pm 0.13$ & $0.27 \pm 0.13$ & $0.3 \pm 0.14$ & - \\
\hline NME & $0.36 \pm 0.19$ & $0.31 \pm 0.18$ & $0.33 \pm 0.18$ & $0.37 \pm 0.19$ & - \\
\hline FAC2 & 0.79 & 0.8 & 0.79 & 0.79 & - \\
\hline CORR & $0.62 \pm 0.08$ & $0.61 \pm 0.06$ & $0.62 \pm 0.07$ & $0.63 \pm 0.08$ & - \\
\hline IOA & $0.45 \pm 0.28$ & $0.47 \pm 0.25$ & $0.46 \pm 0.27$ & $0.47 \pm 0.26$ & - \\
\hline \multicolumn{6}{|c|}{$\mathrm{NO}_{2}-33$ Stations $(N=11465)$} \\
\hline MEAN & $1.31 \pm 1.01$ & $1.37 \pm 1.48$ & $1.33 \pm 1.23$ & $1.57 \pm 1.32$ & $2.31 \pm 1.74$ \\
\hline FB & $-0.47 \pm 0.46$ & $-0.51 \pm 0.53$ & $-0.49 \pm 0.46$ & $-0.28 \pm 0.48$ & - \\
\hline NME & $0.37 \pm 0.25$ & $0.44 \pm 0.27$ & $0.38 \pm 0.25$ & $0.33 \pm 0.23$ & - \\
\hline FAC2 & 0.49 & 0.46 & 0.45 & 0.55 & - \\
\hline CORR & $0.44 \pm 0.31$ & $0.42 \pm 0.3$ & $0.45 \pm 0.3$ & $0.45 \pm 0.3$ & - \\
\hline IOA & $0.41 \pm 0.41$ & $0.35 \pm 0.4$ & $0.41 \pm 0.37$ & $0.48 \pm 0.33$ & - \\
\hline \multicolumn{6}{|c|}{$\mathrm{SO}_{2}-36$ Stations $(N=12430)$} \\
\hline MEAN & $0.98 \pm 0.83$ & $0.98 \pm 1.03$ & $1.09 \pm 1.3$ & $1.27 \pm 1.2$ & $0.78 \pm 0.63$ \\
\hline FB & $0.21 \pm 0.71$ & $0.09 \pm 0.65$ & $0.1 \pm 0.72$ & $0.34 \pm 0.73$ & - \\
\hline NME & $0.8 \pm 0.65$ & $0.63 \pm 0.58$ & $0.7 \pm 0.56$ & $1.03 \pm 0.82$ & - \\
\hline FAC2 & 0.46 & 0.44 & 0.44 & 0.44 & - \\
\hline CORR & $0.4 \pm 0.23$ & $0.38 \pm 0.23$ & $0.38 \pm 0.25$ & $0.4 \pm 0.23$ & - \\
\hline IOA & $0.42 \pm 0.26$ & $0.43 \pm 0.25$ & $0.42 \pm 0.27$ & $0.37 \pm 0.25$ & - \\
\hline \multicolumn{6}{|c|}{$\mathrm{SO}_{4}^{2-}-51$ Stations $(N=17536)$} \\
\hline MEAN & $0.61 \pm 0.18$ & $0.57 \pm 0.18$ & $0.54 \pm 0.17$ & $0.66 \pm 0.21$ & $0.71 \pm 0.42$ \\
\hline FB & $-0.02 \pm 0.4$ & $-0.08 \pm 0.41$ & $-0.13 \pm 0.4$ & $0.06 \pm 0.38$ & - \\
\hline NME & $0.35 \pm 0.33$ & $0.34 \pm 0.32$ & $0.33 \pm 0.27$ & $0.36 \pm 0.38$ & - \\
\hline FAC2 & 0.61 & 0.59 & 0.59 & 0.62 & - \\
\hline CORR & $0.44 \pm 0.16$ & $0.39 \pm 0.15$ & $0.42 \pm 0.15$ & $0.45 \pm 0.16$ & - \\
\hline IOA & $0.49 \pm 0.26$ & $0.43 \pm 0.27$ & $0.44 \pm 0.24$ & $0.51 \pm 0.26$ & - \\
\hline \multicolumn{6}{|c|}{$\mathrm{NH}_{4}^{+}-22$ Stations $(N=7400)$} \\
\hline MEAN & $1.28 \pm 0.77$ & $1.05 \pm 0.6$ & $1.03 \pm 0.64$ & $1.44 \pm 0.9$ & $0.75 \pm 0.78$ \\
\hline FB & $0.74 \pm 0.45$ & $0.59 \pm 0.47$ & $0.57 \pm 0.47$ & $0.83 \pm 0.41$ & - \\
\hline NME & $1.62 \pm 1.31$ & $1.24 \pm 1.1$ & $1.2 \pm 1.14$ & $1.84 \pm 1.38$ & - \\
\hline FAC2 & 0.37 & 0.4 & 0.41 & 0.34 & - \\
\hline CORR & $0.46 \pm 0.17$ & $0.38 \pm 0.21$ & $0.45 \pm 0.18$ & $0.46 \pm 0.18$ & - \\
\hline IOA & $0.14 \pm 0.7$ & $0.25 \pm 0.59$ & $0.25 \pm 0.58$ & $0.09 \pm 0.63$ & - \\
\hline \multicolumn{6}{|c|}{$\mathrm{NO}_{3}^{-}-18$ Stations $(N=6184)$} \\
\hline MEAN & $0.47 \pm 0.41$ & $0.3 \pm 0.24$ & $0.32 \pm 0.31$ & $0.51 \pm 0.46$ & $0.41 \pm 0.54$ \\
\hline FB & $0.05 \pm 0.79$ & $-0.2 \pm 0.79$ & $-0.18 \pm 0.67$ & $0.13 \pm 0.75$ & - \\
\hline NME & $0.78 \pm 0.76$ & $0.58 \pm 0.42$ & $0.37 \pm 0.32$ & $0.81 \pm 1.02$ & - \\
\hline FAC2 & 0.25 & 0.18 & 0.22 & 0.25 & - \\
\hline CORR & $0.32 \pm 0.27$ & $0.26 \pm 0.21$ & $0.32 \pm 0.26$ & $0.32 \pm 0.27$ & - \\
\hline IOA & $0.29 \pm 0.34$ & $0.27 \pm 0.32$ & $0.34 \pm 0.34$ & $0.28 \pm 0.25$ & - \\
\hline
\end{tabular}




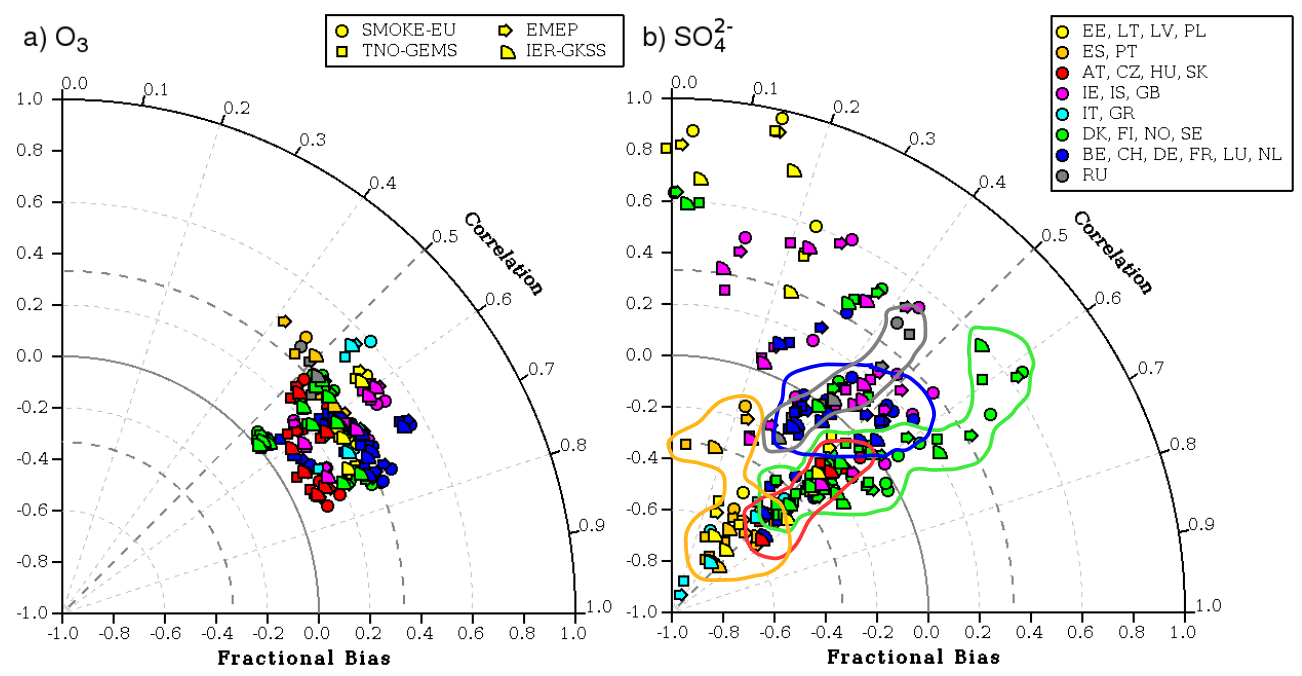

Fig. 15. Diagrams showing correlation and fractional bias of modelled atmospheric concentrations for the year 2000 of (a) $\mathrm{O}_{3}$ and (b) $\mathrm{SO}_{4}^{2-}$ compared to observations. Unlike in standard Tylor diagrams the fractional bias is shown on the radial axis. Different shapes indicate the 4 emission datasets used, while different colours indicate geographical regions. The location of all measurement stations as well as the description of the regions is depicted in Fig. 12.

the boundary layer. This leads to less $\mathrm{SO}_{2}$ in the surface layer because the emissions are distributed over a larger area and, thus, gives them more time to form particles before they reach the surface. Additionally, meteorology may be significantly different at higher altitudes influencing chemical reactions. In the IER-GKSS dataset, on the other hand, all $\mathrm{SO}_{2}$ is emitted in the surface layer, leading to a faster deposition and, therefore, to lower atmospheric $\mathrm{SO}_{2}$ and $\mathrm{SO}_{4}^{2-}$ concentrations. CTM calculations using a version of the EMEP and TNO-GEMS datasets without vertical distribution agree with this finding (Table 6). In most cases, the emissions with vertical distribution show greater correlation, F2 and IOA. Looking at Fig. 15b, some strong regional differences can be observed. Generally Scandinavian (green) measurement sites, with the exception of NO42 (Spitzbergen), have the highest correlations. Central European (blue) sites have the lowest biases, while the concentrations over the Spanish peninsula (orange) are systematically underestimated. A detailed regional analysis is beyond the scope of this paper and will be further discussed elsewhere.

For all four emission datasets, modelled $\mathrm{NH}_{4}^{+}$concentrations are overestimated (Fig. 16a) and show the least agreement with observations of all the species compared (Table 5). This is in agreement with the fact that the $\mathrm{NH}_{3}$ emissions have the highest uncertainties of all the species in the emission datasets. The lowest concentrations and best agreements with observations were simulated using the IER-GKSS emissions. This can be explained by the $\sim 30 \%$ lower $\mathrm{NH}_{3}$ emissions in this dataset (Figs. 4, 5). However, the low $\mathrm{NH}_{3}$ emissions in this dataset also lead
Table 6. Comparison of mean daily concentrations for the year 2000 of $\mathrm{SO}_{4}^{2-}$ and $\mathrm{SO}_{2}$ with and without vertical distribution of the emissions. Values are averages over all measurement stations (51 stations for $\mathrm{SO}_{4}^{2-}, 33$ stations for $\mathrm{SO}_{2}$ ) and their standard deviations. The used measurement stations are described in Table 4.

\begin{tabular}{lcclcc}
\hline & \multicolumn{2}{c}{ EMEP } & & \multicolumn{2}{c}{ TNO-GEMS } \\
\cline { 2 - 3 } \cline { 5 - 6 } & 3D & $2 \mathrm{D}$ & & 3D & 2D \\
\hline $\begin{array}{l}\mathrm{SO}_{4}^{2-} \\
{\left[\mu \mathrm{g} \mathrm{m}^{-3}\right]}\end{array}$ & $0.61 \pm 0.18$ & $0.58 \pm 0.16$ & & $0.55 \pm 0.19$ & $0.54 \pm 0.16$ \\
$\mathrm{SO}_{2}$ & & & & & \\
{$\left[\mu \mathrm{g} \mathrm{m}^{-3}\right]$} & $0.98 \pm 0.83$ & $1.2 \pm 1.18$ & & $0.99 \pm 1.03$ & $1.06 \pm 1.2$ \\
\hline
\end{tabular}

to an underestimation of $\mathrm{NO}_{3}^{-}$concentrations. The higher $\mathrm{NH}_{4}^{+}$values in the SMOKE-EU case lead to an overestimation of $\mathrm{NO}_{3}^{-}$(Fig. 16b). Unexpectedly, the smoother temporal profiles of the IER-GKSS $\mathrm{NH}_{3}$ emissions do not lead to better correlations on the annual scale.

For $\mathrm{NO}_{2}$, CTM results show much higher Fractional Biases (FB) for the SMOKE-EU case (Fig. 16c). Since $\mathrm{NO}_{2}$ is generally underestimated this leads to a higher number of values within a factor of 2 (Table 5). The mean $\mathrm{NO}_{2}$ concentration over all measurement stations given in Table 5 is dominated by high values at two stations IT04 (Ispra) and NL10 (Vredepeel). The comparison of simulated and observed $\mathrm{NO}_{2}$ concentrations show strong spatial differences. Over the Spanish peninsula, where 5 of 33 measurement stations are located, $\mathrm{NO}_{2}$ concentrations are generally underestimated by a factor of 5 . 


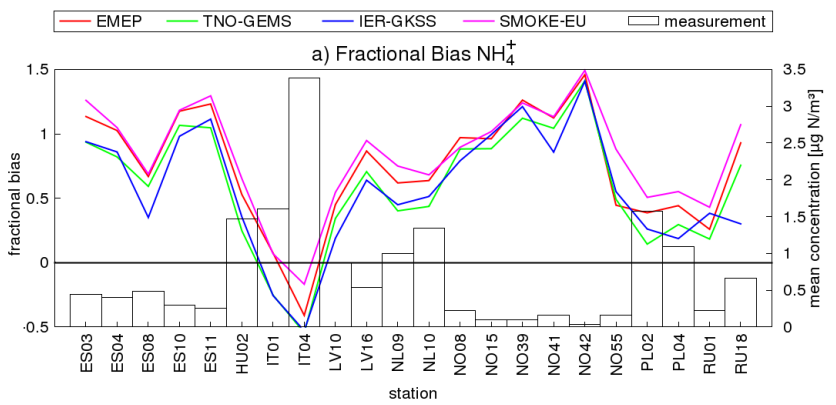

b) Fractional Bias $\mathrm{NO}_{3}^{-}$
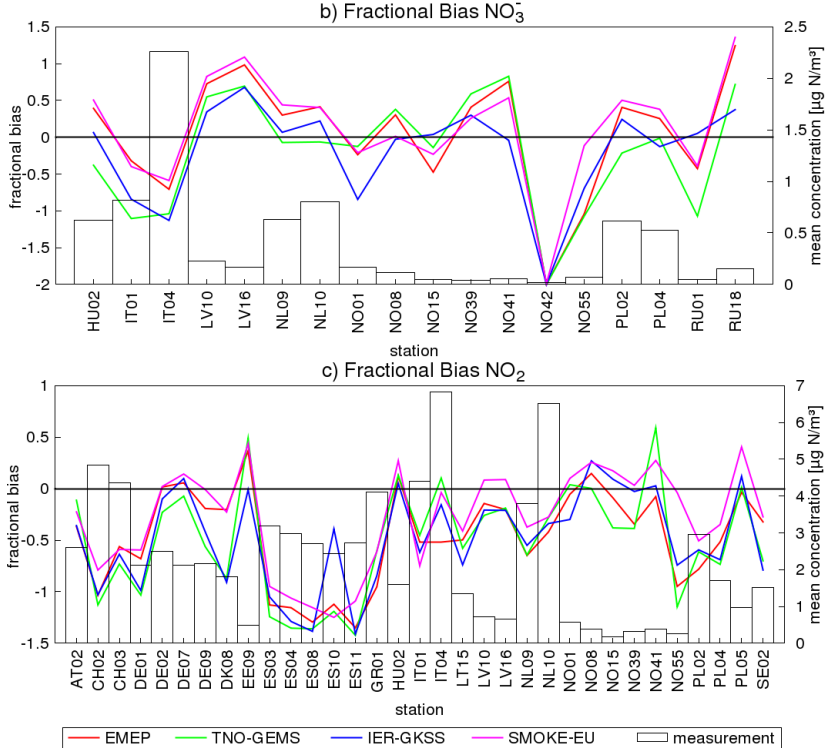

Fig. 16. Fractional bias of modelled $\mathrm{NH}_{4}^{+}, \mathrm{NO}_{3}$ - and $\mathrm{NO}_{2}$ concentrations using four different emission datasets compared to daily mean observations from EMEP measurement stations for the year 2000 (see also Tables 6 and 7).

\section{Conclusions}

The US-EPA SMOKE emission model has been successfully adapted to use publicly available pan-European datasets to create high resolution emission data for Europe. Several preprocessors were developed to transform these datasets into input data required to run SMOKE for Europe (SMOKEEU) model. SMOKE-EU is capable of creating CMAQ ready emission data for the whole of Europe, including western Russia, Turkey and North Africa (Fig. 2). Currently it is used to create emission datasets with spatial resolution in the range of $70 \times 70 \mathrm{~km}^{2}$ down to $10 \times 10 \mathrm{~km}^{2}$. The underlying datasets allow for a spatial resolution as fine as $1 \times 1 \mathrm{~km}^{2}$ (Table 2). Effective emission heights are determined via plume rise calculations. The species calculated by the model are $\mathrm{CO}, \mathrm{SO}_{2}, \mathrm{NO}_{\mathrm{x}}, \mathrm{NH}_{3}, \mathrm{PM}$, and $\mathrm{NMVOC}$ split according to the CB-IV or $\mathrm{CB} 05$ chemical mechanisms.

The SMOKE-EU emissions were compared to datasets from three widely used emission models. These are the TNO-GEMS dataset created by TNO, a dataset from
IER purchased by GKSS and the official gridded EMEP emissions provided by the MSC-W. Comparisons with SMOKE-EU emissions on a $54 \times 54 \mathrm{~km}^{2}$ grid for the year 2000 showed similar total emissions, spatial and temporal distributions of the species. The most significant differences were identified to be the $\mathrm{NH}_{3}$ emissions (Fig. 5) as well as the vertical distributions (Fig. 11). Biogenic emissions lead to significantly higher NMVOC emissions as well as slightly higher NO emission during summer (Fig. 10). For the other species $\left(\mathrm{CO}, \mathrm{SO}_{2}, \mathrm{NO}_{\mathrm{x}}, \mathrm{PM}\right)$ total emissions differed less than $10 \%$ and temporal distributions differed less than $20 \%$.

CMAQ has been used to calculate atmospheric concentrations of air pollutants using the four different emission datasets. Comparison of simulated values with observations from EMEP measurement stations showed that each of the four CTM runs produced sound results (Table 5). The vertical distribution has a strong influence on the simulated $\mathrm{SO}_{4}^{2-}$ and $\mathrm{SO}_{2}$ concentrations (Table 6). Generally, $\mathrm{SO}_{2}$ emissions in higher altitudes have led to higher $\mathrm{SO}_{4}^{2-}$ concentrations near the surface and a better agreement with observations (Fig. 14). The largest differences were found for $\mathrm{NH}_{4}^{+}$and $\mathrm{NO}_{3}^{-}$concentrations (Fig. 16a, b). $\mathrm{NH}_{4}^{+}$ was systematically overestimated while $\mathrm{NO}_{2}$ was strongly underestimated over the Spanish peninsula (Fig. 16b, c). Ozone concentrations, which are strongly influenced by the meteorology, were almost identical for all datasets (Fig. 13).

Emission data created by SMOKE-EU will now be used for European long-term CTM runs for the timespan 19702010. Being a very flexible tool, SMOKE-EU will be further enhanced in the future. Improvements planned include temporal profiles for each country, implementation of other photochemical mechanisms, and the implementation of additional species (i.e., benzo[a]pyrene, mercury).

\section{Appendix A}

\section{Short description of SMOKE and BEIS3 core modules}

SMKINVEN: reads in the raw input data, sorts the records, and creates the SMOKE inventory files that are required by most of the SMOKE programs.

GRDMAT: reads the surrogate files and produces the matrix that contains the factors for spatially allocating the emission sources to the modelling domain.

SPCMAT: calculates the matrices containing split factors for the species speciation.

CNTLMAT: the Cntlmat program uses control packets to create a growth matrix, and/or a multiplicative control matrix, and/or a reactivity control matrix. 
TEMPORAL: reads the temporal profiles and produces a file of hourly inventory pollutant emissions. Unlike the SMOKE matrices produced by Cntlmat, Grdmat and Spcmat, the output file from Temporal contains the actual emissions data.

ELEVPOINT: selects elevated point sources and prepares certain input files for special elevated source or PinG processing.

LAYPOINT: uses the SMOKE point-source inventory file with gridded and hourly meteorology data to compute hourly plume rise for all point sources. The plume rise is expressed in terms of layer fractions for each source.

SMKMERGE: combines the matrices produced by the other SMOKE programs to produce the emissions files for input to the CTM. The Smkmerge program may be run on any combination of source types and may incorporate temporal, speciation, projection, and spatial processing.

NORMBEIS: reads gridded land use data and emissions factors and produces gridded normalized biogenic emissions.

METSCAN: determines winter and summer seasons depending on surface temperature.

TMPBEIS3: uses temperature, surface pressure and radiation data from meteorological files to calculate hourly biogenic emissions.

\section{Appendix B}

\section{Statistical measures used for comparisons}

$P_{i}=$ Predicted value from Model

$O_{i}=$ Observed value

$N=$ sample size

Mean $\bar{O}=\frac{1}{N} \sum_{i=1}^{N} O_{i} \quad \bar{P}=\frac{1}{N} \sum_{i=1}^{N} P_{i}$

Fractional Bias $(\mathrm{FB}) \mathrm{FB}=\frac{\bar{P}-\bar{O}}{0.5(\bar{P}+\bar{O})}$

Mean Normalized Bias (NMB)

$$
\mathrm{MNB}=\frac{1}{N} \sum_{i=1}^{N}\left(\frac{P_{i}-O_{i}}{O_{i}}\right)
$$

Mean Normalized Error (MNE)

$$
\mathrm{MNE}=\frac{1}{N} \sum_{i=1}^{N}\left(\frac{\left|P_{i}-O_{i}\right|}{O_{i}}\right)
$$

Normalized Mean Error (NME)

$$
\mathrm{NME}=\frac{|\bar{P}-\bar{O}|}{\bar{O}}
$$

Standard Deviation

$$
\sigma_{o}=\sqrt{\frac{1}{N} \sum_{i=1}^{N}\left(O_{i}-\bar{O}\right)^{2}}
$$

Correlation coefficient

$$
r=\frac{\frac{1}{N} \sum_{i=1}^{N}\left(O_{i}-\bar{O}\right)\left(P_{i}-\bar{P}\right)}{\sigma_{o} \sigma_{p}}
$$

Index of Agreement (IOA)

$$
\mathrm{IOA}=1-\frac{\sum_{i=1}^{N}\left(P_{i}-O_{i}\right)^{2}}{\sum_{i=1}^{N}\left(\left|P_{i}-\bar{P}\right|+\left|O_{i}-\bar{O}\right|\right)^{2}}
$$

Factor of 2 (F2)

$$
\text { FAC2 }=\frac{1}{N} \sum_{i=1}^{N} n_{i} \text { with } n_{i}=1 \text { for } 0.5<\left|\frac{P_{i}}{O_{i}}\right| \leq 2
$$

\section{Appendix C}

\section{Abbreviations}

$\begin{array}{ll}\text { CLC } & \text { Corine Air Land Cover database } \\ \text { CMAQ } & \text { Community Modelling Air Quality } \\ \text { CMAS } & \text { Community Modelling Air quality System } \\ \text { CORINAIR } & \text { Core Inventory of Air emissions } \\ \text { CLM } & \text { Climate version of the Lokal Model } \\ \text { CTM } & \text { Chemical Transport Model } \\ \text { DCW } & \text { Digital Chart of the World } \\ \text { DMA } & \text { Defense Mapping Agency } \\ \text { EMC } & \text { Environmental Modelling Center (USA) } \\ \text { EMEP } & \text { European Monitoring and Evaluation Program } \\ \text { EEA } & \text { European Environmental Agency } \\ \text { EPA } & \text { Environmental Protection Agency (USA) } \\ \text { EPER } & \text { European Pollutants Emission Register } \\ \text { ESRI } & \text { Environmental Systems Research Institute } \\ \text { EU15 } & \text { European Union 15 Member states } \\ \text { EU27 } & \text { European Union 27 Member states } \\ \text { EUROSTAT } & \text { European Statistical Service } \\ \text { FIPS U.S. } & \text { Federal Implementation Planning Standards } \\ \text { GEMS } & \text { Global and regional Earth-system Monitoring } \\ & \text { using Satellite and in-situ }\end{array}$




\begin{tabular}{|c|c|}
\hline GLC & Global Land Cover database \\
\hline GPS & Global Positioning System \\
\hline GPW & Gridded Population of the World \\
\hline $\mathrm{HM}$ & Heavy Metals \\
\hline IER & Institute for Rational use of Energy \\
\hline LRTAP & $\begin{array}{l}\text { Convention on Long-Range Transport of Air } \\
\text { Pollutants }\end{array}$ \\
\hline MM5 & $\begin{array}{l}\text { The Fifth-Generation NCAR/Penn State } \\
\text { Mesoscale Meteorological Model }\end{array}$ \\
\hline MSC-W & Meteorological Synthesizing Center - West \\
\hline NMVOC & Non-Methane Volatile Organic Compounds \\
\hline NACE & $\begin{array}{l}\text { Nomenclature statistique des activités } \\
\text { économiques dans la é européenne }\end{array}$ \\
\hline NUTS & Nomenclature of Units for Territorial Statistics \\
\hline OMS & OpenStreetMaps \\
\hline PM & Particulate Matter \\
\hline $\mathrm{PM}_{2.5}$ & Particulate Matter smaller than $2.5 \mu \mathrm{m}$ \\
\hline $\mathrm{PM}_{10}$ & Particulate Matter smaller than $10 \mu \mathrm{m}$ \\
\hline POP & Persistent Organic Pollutants \\
\hline RIVM & $\begin{array}{l}\text { National Institute for Public Health and the } \\
\text { Environment (NL) }\end{array}$ \\
\hline SCC & Source Classification Code \\
\hline SNAP & $\begin{array}{l}\text { Selected Nomenclature for sources of Air } \\
\text { Pollution }\end{array}$ \\
\hline SMOKE-EU & SMOKE for Europe \\
\hline SMOKE & Sparse Matrix Operator Kernel Emissions \\
\hline TNO & $\begin{array}{l}\text { Netherlands Organization for Applied } \\
\text { Scientific Research (NL) }\end{array}$ \\
\hline UCAR & $\begin{array}{l}\text { University Cooperation for Atmospheric } \\
\text { Research }\end{array}$ \\
\hline UBA & Federal Environmental Agency (DE) \\
\hline UNC & University of North Carolina \\
\hline USGS & United States Geological Survey \\
\hline VOC & Volatile Organic Compounds \\
\hline
\end{tabular}

\section{Supplementary material related to this article is available online at: http://www.geosci-model-dev.net/4/47/2011/ gmd-4-47-2011-supplement.pdf.}

Acknowledgements. US EPA is gratefully acknowledged for the use of SMOKE and CMAQ. We are thankful to Beate Geyer for providing the CLM meteorological fields and to Hugo Denier van der Gon for the GEMS emission data. We want to thank EMEP and IER Stuttgart for providing emission data. Finally, the authors want to thank the numerous providers of the open source online databases used for this publication.

Edited by: P. Jöckel

\section{References}

Andersson, C. and Langner, J.: Inter-annual Variations of Ozone and Nitrogen Dioxide Over Europe During 1958-2003 Simulated with a Regional CTM, Water Air Soil Pollut., 7, 15-23, 2005.

Agrawal, H., Malloy, Q. G. J., Welch, W. A., Miller, J. W., and Cocker, D. R.: In-use gaseous and particulate matter emissions from a modern ocean going container vessel, Technical note, Atmos. Environ., 42, 5504-5510, 2008.

Aulinger, A., Matthias, V., and Quante, M.: An approach to temporally disaggregate Benzo(a)pyrene emissions and their application to a 3D Eulerian atmospheric chemistry transport model, Water Air Soil Pollut., online first, doi:10.1007/s11270010-0559-x, 2010.

Baek, B.,H., Seppanen, C., and Houyoux, M.: SMOKE v2.6 User's manual, available online at: http://www.smoke-model. org/version2.6/, last access: 1 May 2009.

Balk, D. and Yetman, G.: The Global Distribution of Population: Evaluating the gains in resolution refinement, Center for International Earth Science Information Network (CIESIN) Columbia University, Columbia, USA, 2004.

Benedictow, A., Fagerli, H., Gauss, M., Jonson, J. E., Nyiri, A., Simpson, D., Tsyro, S., Valdebenito, A., Valiyaveetil, S., Wind, P., Aas, W., Hjelbrekke, A., Marechova, K., Wankmueller, R., Harmens, H., Cooper, D., Norris, D., Schroeder, W., Pesch, R., and Holy, M: Transboundary Acidification, Eutrophication and Ground Level Ozone in Europe in 2007, EMEP Status Report 2009; July 16, 2009, Norwegian Meteorological Institute (NMI), Oslo, Norway, ISSN 1504-6109 (print), ISSN 1504-6192 (online), 2009.

Benkovitz, M. C., Akimoto, H., Corbett, J. J., Mobley, J. D., Ohara, T., Olivier, J. G. J., van Ardenne, J. A., and Vestreng, V.: Compilation of Regional to Global Inventories of Anthropogenic Emissions, in: Emissions of Atmoshperic Trace Compounds, edited by: Granier, C., Artaxo, P., and Reeves, C. E., Kluwer Academic Publishers, Dordrecht, 17-69, 2004.

Borge, R., Lumbreras, J., and Encarnacion, R.: Development of a high-resolution emission inventory for Spain using the SMOKE modelling system: A case study for the years 2000 and 2010, Environ. Modell. Softw., 23, 1026-1044, 2008.

Briggs, G. A.: Discussion on Chimney Plumes in Neutral and Stable Surroundings, Atmos. Environ., 6, 507-510, 1972.

Builtjes, P. J. H., van Loon, M., Schaap, M., Teeuwisse, S., Visschedijk, A. J. H., and Bloos, J. P.: Abschlussbericht zum FE-Vorhaben 29841 252: "Modellierung und Prüfung von Strategien zur Verminderung der Belatung durch Ozon" Contribution of TNO-MEP. TNO-report R2003/166, 2003

Byun, D. W. and Ching, J. K. S.: Science Algorithms of the EPA Models-3 Community Multi-scale Air Quality (CMAQ) Modeling System, EPA/600/R-99/030, US EPA National Exposure Research Laboratory, Research Triangle Park, NC, 1999.

Byun, D. W. and Schere, K. L.: Review of the governing equations, computational algorithms, and other components of the Models3 community Multiscale Air Quality (CMAQ) modeling system, Appl. Mech. Rev., 59(2), 51-77, 2006.

Digital Chart of the World: http://www.maproom.psu.edu/dcw/, last access: January 2010.

Corine Land Cover: http://www.eea.europa.eu/data-and-maps/ data/, last access: March 2010. 
EPA: Technology Transfer Network, Clearinghouse for Inventories \& Emission Factors, available at: http://www.epa.gov/ttn/chief/, last access: March 2010.

European Commission: Commission Decision 2000/479/EC of 17 July 2000 on the implementation of a European pollutant emission register (EPER) according to Article 15 of Council Directive 96/61/EC concerning integrated pollution prevention and control (IPPC), Official Journal of the European Communities, EC, 1049 Brussel, Belgium, L. V192, 36-43, 2000.

European Commission: Regulation (EC) No 1059/2003 of the European Parliament and of the Council of 26 May 2003 on the establishment of a common classification of territorial units for statistics (NUTS), EC, 1049 Brussel, Belgium, Official Journal of the European Communities, L. V154, 1-41, 2003.

European Commission: TREMOVE Service contract for the further development and application of the transport and environmental TREMOVE model Lot 1 (Improvement of the data set and model structure), EC, 1049 Brussel, Belgium, Final Report, Service Contract 070501/2005/420798/MAR/C1, 2007.

European Environmental Agency: EMEP/CORINAIR emission inventory guidebook, EEA, 1049 Brussel, Belgium, Technical Report No. 16/2007, 2007.

European Pollution Emission Register: http://www.eper.ec.europa. eu/eper/extract_data.asp, last access: January 2010.

EUROSTAT: http://epp.eurostat.ec.europa.eu/portal/page/portal/ statistics/search_database, last access: March 2010.

Friedrich, R. and Reis, S.: Emissions of air pollutants, Springer, Berlin Heidelberg New York, 2004.

Gery, M. W., Whitten, G. Z., Killus, J. P., and Dodge, M. C.: A photochemical kinetics mechanism for urban and regional scale computer modeling, J. Geophys. Res., 94(D10), 12925-12956, 1989.

Guenther, A., Geron, C., Pierce, T., Lamb, B., Harley, P., and Fall, R.: Natural emissions of non-methane volatile organic compounds, carbon monoxide, and oxides of nitrogen from North America, Atmos. Environ., 34, 2205-2230, 2000.

Hanna, S. R. and Davis, J. M.: Uncertainties in predicted ozone concentrations due to input uncertainties for the UAM$\mathrm{V}$ photochemical grid model applied to the July 1995 OTAG domain, Atmos. Environ., 35(5), 891-903, 2001.

Horowitz, L. W., Walters, S., Mauzerall, D. L., Emmons, L. K., Rasch, P. J., Granier, C., Tie, X., Lamarque, J.-F., Schultz, M. G., Tyndall, G. S., Orlando, J. J., and Brasseur, G. P.: A global simulation of tropospheric ozone and related tracers: Description and evaluation of MOZART, version 2, J. Geophys. Res., 108, 4784, doi:10.1029/2002JD002853, 2003.

Houyoux, M. R.: Technical report: plume rise algorithm summary for the Sparse Matrix Operator Modeling System (SMOKE). Prepared for North Carolina Department of Environment and Natural Resources, UNC, Chapel Hill, North Carolina, ENV98TR004eTR0v1.0, 1998.

Houyoux, M. R., Vukovich, J. M., Coats Jr., C. J., Wheeler, N. J. M., and Kasibhatla, P. S.: Emission inventory development and processing for the Seasonal Model for Regional Air Quality (SMRAQ) project, J. Geophys. Res., 105(D7), 9079-9090, 2000.

Mareckova, K., Wankmueller, R., Anderl, M., Muik, B., Poupa, S., and Wieser, M.: Inventory Review 2008, Emission data reported under the LRTAP Convention and NEC Directive, Stage 1 and 2 review, Status of gridded data, EEA \& CEIP, 2008.
Mareckova, K., Wankmueller, R., Pazdernik, K., Purzner, M., Zechmeister, A., Joebstl, R., and Adams, M.: Inventory Review 2010, Review of emission data reported under the LRTAP Convention and NEC Directive, Stage 1 and 2 review, Status of gridded data and LPS data, EEA \& CEIP, 2010.

Maes, J., Vliegen, J., van de Vel, K., Janssen, S., Deutsch, F., de Ridder, K., and Mensink, C.: Spatial surrogates for the disaggregation of CORINAIR emission inventories, Atmos. Environ., 43, 1246-1254, 2009.

Matthias, V., Aulinger, A., and Quante, M.: Determination of the optimum MM5 configuration for long term CMAQ simulations of aerosol bound pollutants in Europe, Environ. Fluid Mech., 9(1), 91-108, 2009.

MCNC-Environmental Modeling Center: Sparse Matrix Operational Kernel Emissions Modeling System, available at: http://www.cmascenter.org/download/forms/step_1.cfm? $\mathrm{CFID}=2077553 \backslash \& \mathrm{CFTOKEN}=19843259$, last access: May 2008.

Niemeier, U., Granier, C., Kornblueh, L., Walters, S., and Brasseur, G. P.: Global impact of road traffic on atmospheric chemical composition and on ozone climate forcing, J. Geophys. Res., 111, D09301, doi:10.1029/2005JD006407, 2006.

Olivier, J. G. J. and Berdowski, J. J. M.: Global emissions sources and sinks, in: The Climate System, edited by: Berdowski, J., Guichert, R., and Heij, B. J., A.A. Balkema Publishers/Swets \& Zeitlinger Publishers, Lisse, The Netherlands, 33-78, 2001.

Openstreetmap: http://planet.openstreetmap.org/planet-100106. osm.bz2, last access: January 2010.

Passant, N.: Speciation of UK emissions of non-methane volatile organic compounds, AEA Technology, Culham Abingdon Oxon, GB, AEAT/R/ENV/0545, February 2002.

Pregger, T. and Friedrich, R.: Effective pollutant emission height for atmospheric transport modelling based on real-world information, Environ. Pollut., 157, 552-560, 2009.

Rockel, B. and Geyer, B.: The performance of the regional climate model CLM in different climate regions, based on the example of precipitation. Meteorologische Zeitschrift Band 17, Heft 4, 487498, 2008.

Rockel, B., Will, A., and Hense, A.: The Regional Climate Model COSMO-CLM (CCLM), Meteorol. Z., 17, 347-248, 2008.

Russell, D.: NARSTO critical review of photochemical models and modelling, Atmos. Environ., 34(12-14), 2261-2282, 2000.

Schlünzen, K. H. and Sokhi, R. S.: Overview of tools and methods for meteorological and air pollution mesoscale model evaluation and user training, WMO, Geneva, Switzerland, Joint Report of COST Action 728 and GURME, GAW Repert No. 181, 2008.

Schaap, M., Roemer, M., Sauter, F., Boersen, G., Timmermans, R., Builtjes, P. J. H., and Vermeulen, A. T.: LOTOSEUROS documentation, available at: http://www.lotos-euros.nl/ doc/index.html (last access: January 2010), 2005.

Schwede, D., Pouliot, G., and Pierce, T.: Changes to the Biogenic Emissions Inventory System Version 3 (BEIS3). 4th CMAS Models-3 Users' Conference, Chapel Hill, NC, 26-28 September 2005.

Sedac: Gridded Population of the World v3, available at: http: //sedac.ciesin.columbia.edu/gpw/global.jsp, last access: January 2010.

Seaman, N. L.: Meteorological modeling for air-quality assessments, Atmos. Environ., 34(12-14), 2231-2259, 2000. 
Simpson, D., Fagerli, H., Jonson, J. E., Tsyro, S., Wind, P., and Tuovinen, J.: Transboundary Acidification, Eutrophication and Ground Level Ozone in Europe Part I Unified EMEP Model Description, EMEP Status Report 2003, Norwegian Meteorological Institute, NMI, Oslo, Norway, 2007.

Smiatek, G.: Mapping land use for modelling biogenic and anthropogenic emissions, in: The Proceedings of the EUROTRAC2 Symposium '98, Boston Southampton 2000, edited by: Borrell, P. M. and Borrell, P., WIT Press, UK, ISBN 1-85312-743-4, 1765 pp., 1998.

Sofiev, M., Miranda, A. I., and Sokhi, R.: Review of the Capabilities of Meteorological and Chemistry-Transport Models for Describing and Predicting Air Pollution Episodes, (WMO/TDNo. 1502), Technical report, COST 728 and GURME, Geneva, 2009.

TREMOVE: http://www.tremove.org/documentation/index.htm, last access: January 2010.

UNC Carolina Environmental Program: Sparse Matrix Operator Kernel Emissions (SMOKE) Modeling System, UNC Chapel Hill, North Carolina, USA, 2005.

US Environmental Protection Agency: Community Multiscale Air Quality Modeling System, available at: http://www.epa.gov/ asmdnerl/models3/, last access: August 2009.
USGS Global Land Cover Characterization: http://edc2.usgs.gov/ glcc/glcc.php, last access: January 2009.

Vautard, R., Beekmann, M., Bessagnet, B., and Menut, L.: Chimere Un simulateur numerique de la qualite de l'air, IPSL, Paris, France, 2007 (in French).

Vestreng, V., Mareckova, K., Kakareka, S., Malchykhina, A., and Kukharchyk, T.: Inventory Review 2007. Emission Data Reported to LRTAP Convention and NEC Directive, MSC-West, Oslo, Norway, MSC-W Technical Report 1/07, 2007.

Visschedijk, A. J. H. and Denier van der Gon, H. A. C. Gridded European anthropogenic emission data for $\mathrm{NO}_{\mathrm{x}}, \mathrm{SO}_{2}$, NMVOC, $\mathrm{NH}_{3}, \mathrm{CO}, \mathrm{PM}_{10}, \mathrm{PM}_{2.5}$ and $\mathrm{CH}_{4}$ for the year 2000, TNO, Appeldoorn, Netherlands, TNO-report B\&O-A R2005/106 version2, 2005.

Visschedijk, A. J. H., Zandveld, P., and Denier van der Gon, H. A C.: A high resolution gridded European emission database for the EU integrated project GEMS, TNO, Apeldoorn, Netherlands, TNO-report 2007-A-R0233/B, 2007.

Webdab: http://www.ceip.at/emission-data-webdab/ emissions-used-in-emep-models/, last access: January 2010.

Yu, Y., Sokhi, R. S., Kitwiroon, N., Middleton, D. R., and Fisher, B.: Performance characteristics of MM5-SMOKE-CMAQ for a summer photochemical episode in southeast England, United Kingdom, Atmos. Environ., 42, 4870-4883, 2008. 